\title{
Between Heroes and Guardians: General Lyman L. Lemnitzer and General Charles H. Bonesteel III
}

A Monograph

By

MAJ Justin Nelson

United States Army

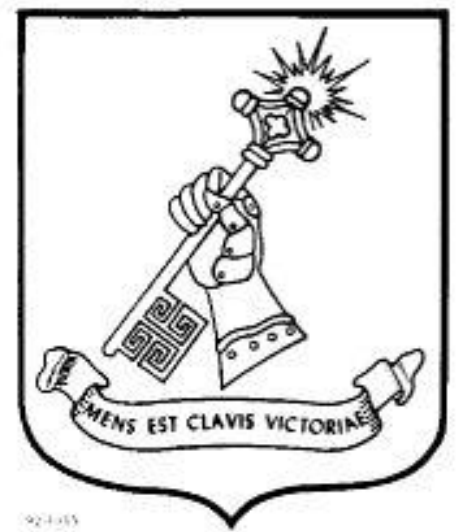

School of Advanced Military Studies

United States Army Command and General Staff College

Fort Leavenworth, Kansas

2015-01 


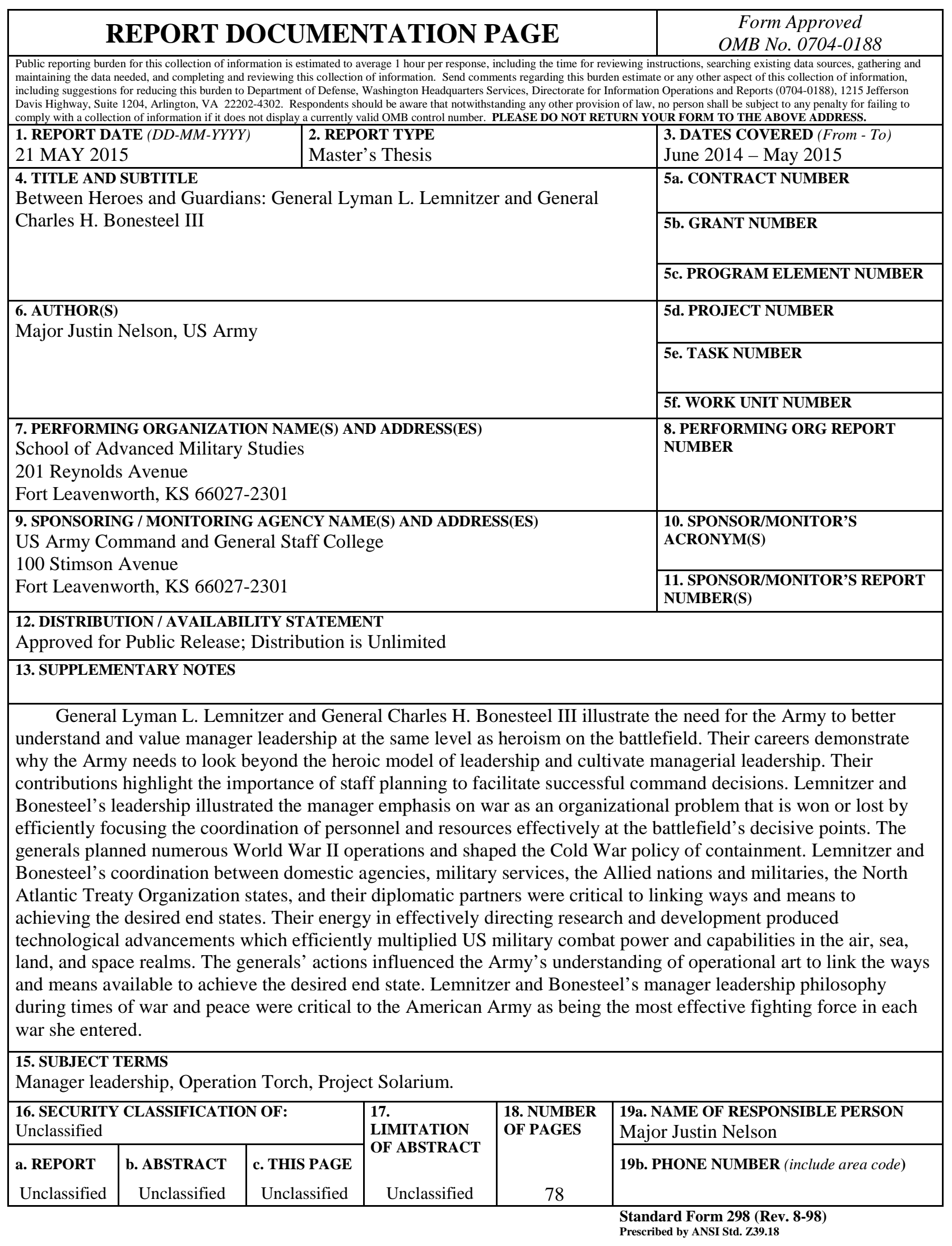




\section{Monograph Approval Page}

Name of Candidate: MAJ Justin Nelson

Monograph Title: $\quad$ Between Heroes and Guardians: General Lyman L. Lemnitzer and General Charles H. Bonesteel III

Approved by:

Robert T. Davis II, PhD

, Monograph Director

, Seminar Leader

Craig Berryman, COL

, Director, School of Advanced Military Studies

Henry A. Arnold III, COL

Accepted this $21^{\text {st }}$ day of May 2015 by:

, Director, Graduate Degree Programs

Robert F. Baumann, PhD

The opinions and conclusions expressed herein are those of the student author and do not necessarily represent the views of the U.S. Army Command and General Staff College or any other government agency. (References to this study should include the foregoing statement.) 


\begin{abstract}
Between Heroes and Guardians: General Lyman L. Lemnitzer and General Charles H. Bonesteel, by MAJ Justin Nelson, US Army, 78 pages.

General Lyman L. Lemnitzer and General Charles H. Bonesteel III illustrate the need for the Army to better understand and value manager leadership at the same level as heroism on the battlefield. Their careers demonstrate why the Army needs to look beyond the heroic model of leadership and cultivate managerial leadership. Their contributions highlight the importance of staff planning to facilitate successful command decisions. Lemnitzer and Bonesteel's leadership illustrated the manager emphasis on war as an organizational problem that is won or lost by efficiently focusing the coordination of personnel and resources effectively at the battlefield's decisive points. Lemnitzer and Bonesteel influenced the US Army's understanding of operational art from their actions in planning operations, coordinating between institutions, and driving research and development to facilitate the incorporation of the ways and means available to achieve strategic end states for America. The generals planned numerous World War II operations and shaped the Cold War policy of containment. Lemnitzer and Bonesteel's coordination between domestic agencies, military services, the Allied nations and militaries, the North Atlantic Treaty Organization states, and their diplomatic partners were critical to linking ways and means to achieving the desired end states. Their energy in effectively directing research and development produced technological advancements which efficiently multiplied US military combat power and capabilities in the air, sea, land, and space realms. The generals' actions influenced the Army understanding of operational art to link the ways and means available to achieve the desired end state. Lemnitzer and Bonesteel's manager leadership philosophy during times of war and peace were critical to the American Army as being the most effective fighting force in each war she entered.
\end{abstract}




\section{Table of Contents}

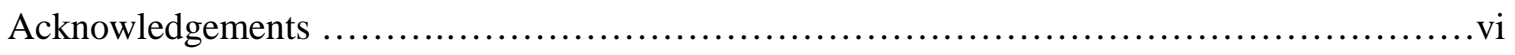

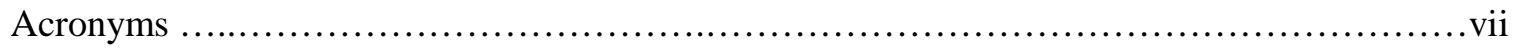

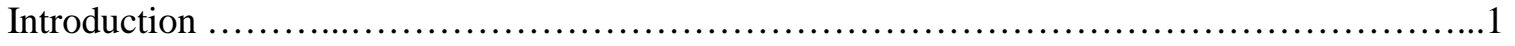

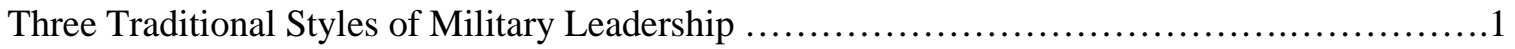

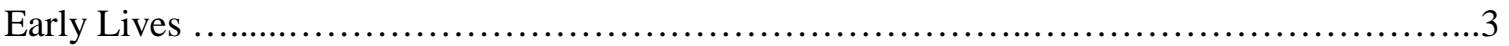

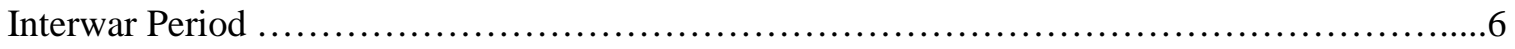

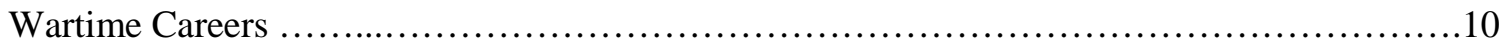

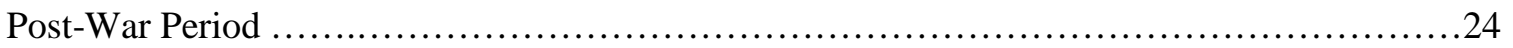

Conclusion ...........................................................................

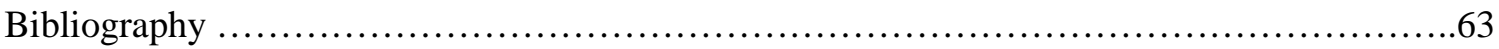




\section{Acknowledgments}

I appreciate the support from my monograph director and seminar leader. Dr. Robert Davis' relaxed approach and depth of knowledge allowed me to develop my research and writing, while providing precise course corrections when needed. Likewise, Colonel Craig Berryman contributed greatly to my growth as a student and writer. Their hands-off methods allowed me to complete the Masters of Arts in Security Studies from Kansas State University while staying on course. The lessons learned from both of these men will help me during and beyond my utilization tour. Thanks again.

My greatest thanks goes to my wife and toddlers for their patience over the last ten months. Despite many long hours and weekends of work, they never complained and always greeted me home with a hug. I can only hope to make up some lost time at our next post in Texas. 


\section{Acronyms}

$\begin{array}{ll}\text { AEF } & \text { American Expeditionary Forces } \\ \text { CIA } & \text { Central Intelligence Agency } \\ \text { CINCUNC } & \text { Commander in Chief United Nations Command } \\ \text { DUKW } & \text { 'D' designed in 1942, 'U' utility vehicle, 'K' all-wheel drive, 'W' dual rear axles } \\ \text { ICBM } & \text { intercontinental ballistic missile } \\ \text { MAD } & \text { mutually assured destruction } \\ \text { NASA } & \text { National Aeronautics and Space Administration } \\ \text { NATO } & \text { North Atlantic Treaty Organization } \\ \text { NKPA } & \text { North Korean People's Army } \\ \text { NSC } & \text { National Security Council } \\ \text { OER } & \text { Officer Evaluation Report } \\ \text { OSS } & \text { Office of Strategic Services } \\ \text { ROK } & \text { Republic of Korea } \\ \text { SACEUR } & \text { Supreme Allied Commander Europe } \\ \text { SHAPE } & \text { Supreme Headquarters Allied Powers Europe } \\ \text { SIOP } & \text { Single Integrated Operational Plan } \\ \text { SS } & \text { Schutzstaffel troops } \\ \text { USCINCEUR } & \text { US Commander in Chief European Command } \\ \text { USFK } & \text { US Forces Korea }\end{array}$




\section{Introduction}

General Lyman L. Lemnitzer and General Charles H. Bonesteel III influenced the US Army's understanding of operational art with strategic and operational leadership during their eighty-seven cumulative years of total Army service. Lemnitzer and Bonesteel’s actions in planning operations, institutional coordination, and driving research and development facilitated the incorporation of the ways and means available to achieve strategic end states for America. The majority of an Army officer's career is not spent leading troops as a commander, but is spent as a staff officer or serving under someone else. Generals Lemnitzer and Bonesteel planned operations and shaped doctrine to set necessary conditions to successfully achieve their higher headquarters’ desired end states against the current and future enemy threats.

Brian Linn categorizes three traditional styles of military leadership philosophy in his book, The Echo of Battle: The Army's Way of War, as managers, guardians, and heroes. ${ }^{1}$ Generals Lemnitzer and Bonesteel were manager leaders. Managers emphasize war as an organizational problem that is won or lost by efficiently focusing the coordination of personnel and resources effectively at the battlefield's decisive points. ${ }^{2}$ Lemnitzer and Bonesteel's coordination between institutions at varying echelons of domestic, defense, diplomatic, and alliance levels were critical to effectively linking ways and means to achieving the desired end states. Their energy in directing research and development resulted in efficient technological advancements multiplied US military combat power in the realms of air, sea, land, and space. This monograph illuminates a key aspect of leadership and why the Army should be interested in the confident, competent

${ }^{1}$ Brian McAllister Linn, The Echo of Battle: The Army's Way of War (Cambridge: Harvard University Press, 2007), 5.

${ }^{2}$ Linn, 8-9. 
leadership style demonstrated by manager Generals Lemnitzer and Bonesteel as it develops future leaders. ${ }^{3}$

This paper demonstrates the importance of the manager leadership style by exploring Lemnitzer and Bonesteel's linkage of tactical actions in time, space, and purpose through the effective arrangement of personnel and resources at decisive points to achieve strategic objectives. Current Army leadership is defined as "motivating people both inside and outside the chain of command to pursue actions, focus thinking, and make decisions that accomplish the mission [with actions to include] acting decisively, within the intent and purpose of superior leaders, and in the best interest of the organization." ${ }^{4}$ Operational art is defined in Unified Land Operations as "the pursuit of strategic objectives, in whole or in part, through the arrangement of tactical actions in time, space, and purpose." ${ }^{5}$ The application of operational art is "the cognitive approach by commanders and staffs — supported by their skill, knowledge, experience, creativity, and judgment — to develop strategies, campaigns, and operations to organize and employ military forces by integrating ends, ways, and means.”6 An increased emphasis on manager leadership within the Army's understanding of leadership would better mold future leaders for understanding, applying, and performing operational art to achieve strategic objectives.

The American citizen is generally familiar with the practitioners of heroic leadership styles on the battlefield. Names like Generals MacArthur, Patton, Ridgway, Gavin, and Taylor

3 'Manager leadership' is defined as a planner's skill at magnifying every available means and ways in a concentrated manner at strategic decisive points to achieve the desired end states on the battlefield or the strategic critical tasks at hand.

${ }^{4}$ Army Doctrine Reference Publication (ADRP) 6-0, Mission Command (Washington, DC: Headquarters Department of the Army, May 2012), 27.

${ }^{5}$ Army Doctrine Publication (ADP) 3-0, Unified Land Operations (Washington, DC: Headquarters Department of the Army, October 2011), 9.

${ }^{6}$ Army Doctrine Reference Publication (ADRP) 5-0, The Operations Process (Washington, DC: Headquarters Department of the Army, May 2012), 28. 
resonate in our history. The average American is not familiar with the practitioners of manager leadership style, like Generals Lemnitzer and Bonesteel, who during times of war and peace are critical to maintaining the US Army as the most effective fighting force prior to periods of conflict. Generals Lemnitzer and Bonesteel demonstrated manager characteristics during the majority of their careers by efficiently focusing the coordination of organizational personnel and resources at various missions' decisive points. ${ }^{7}$ Patrick Rose documented how managerial leadership styles were taught in pre-World War II era American business and military institutions to intensify resources at the decisive point of time most important to production or goal accomplishment. ${ }^{8}$ Guardians emphasize war as an engineering problem making war predictable by the application of the correct principles and policies gained through institutional knowledge. ${ }^{9}$ Heroes emphasize war as a human problem that is won or lost from the characteristics of individual people in warfare, including their "military genius, experience, courage, morale, and discipline,” to adapt and innovate tactics on the battlefield. ${ }^{10}$ Each military leadership philosophy modifies its concepts over time due to the ever-changing evolutions in technology on the battlefield, but their core philosophies of leadership styles remain the same. There is a need for the Army to understand and value leadership beyond the heroism of generals on the battlefield.

\section{The Early Life of General Lyman L. Lemnitzer}

General Lyman L. Lemnitzer served in the US Army for forty-nine years. ${ }^{11}$ He was commissioned in 1920 as a Coastal Artillery Corps Second Lieutenant from the US Military

\footnotetext{
${ }^{7}$ Linn, 8-9.

${ }^{8}$ Patrick Rose, "Allies at War: British and US Army Command Culture in the Italian Campaign, 1943-1944,” Journal of Strategic Studies 36, no. 1 (February 12, 2013): 51-52, accessed February 11, 2015, http://dx.doi.org/10.1080/01402390.2012.745398.

${ }^{9}$ Linn, 7-8.

${ }^{10}$ Ibid., 6.

${ }^{11}$ L. James Binder, Lemnitzer: A Soldier for His Time (Washington, DC: Brassey’s Books, 1997), 2.
} 
Academy. ${ }^{12}$ He retired in 1969 as the dual-hatted commander in chief of the U.S. European Command (USCINCEUR) and the Supreme Allied Commander Europe (SACEUR) of the North Atlantic Treaty Organization (NATO). ${ }^{13}$ During his career, he served on multiple operational and strategic level staffs and commanded troops up to the Army level. These experiences included the following: planned the Allied invasion of North Africa during World War II and facilitated the surrender of German troops in Italy, helped establish NATO and expand the concept of military assistance in the late 1940s, contributed to Project Solarium, reduced the US military security requirements in Korea, advanced Army space exploration in 1958, and became an accomplished soldier-diplomat. Lemnitzer’s experience and actions facilitated the incorporation of ways and means which contributed to the US Army's understanding of operational art.

Lemnitzer's performance while working in partnership with civilians and civilian agencies set him apart from his peers. His Officer Evaluation Reports (OER) began to reflect this unique quality while working at the US Military Academy in the mid-1920s. ${ }^{14}$ Lemnitzer's ability to work well with civilians derived from his respect for civilian control over the military and the appreciation of civil-military relations benefitted his civil-military interactions throughout the numerous senior positions he held in Asia, NATO, Europe, and Washington, DC. ${ }^{15}$ In doing so, Lemnitzer avoided creating enemies while deftly communicating ideas that lacked unanimous

\footnotetext{
${ }^{12}$ Walter S. Poole, The Joint Chiefs of Staff and National Policy, 1961-64, v. 8 (Washington, DC: Office of Joint History, 2011), 202; Binder, 35, 311; Lawrence S. Kaplan, NATO 1948: The Birth of the Transatlantic Alliance (Lanham, MD: Rowman and Littlefield, 2007), 145.

${ }^{13}$ Poole, 202; Binder, 35, 311; Kaplan, 145.

${ }^{14}$ Binder, 51.

${ }^{15}$ Richard M. Nixon, "Remarks on Presenting the Distinguished Service Medals of the Army, Navy, and Air Force to General Lyman L. Lemnitzer, July 11 1 th 1969," Public Papers of the Presidents of the United States: Richard M. Nixon, 1969 (Washington, DC: Government Printing Office, 1971), 506; Binder, 281.
} 
agreement from all perspectives. ${ }^{16}$ Lemnitzer's teamwork ability to work with civilians while representing the military and manager leadership made him a strong team player for achieving operational and strategic goals.

\section{The Early Life of General Charles H. Bonesteel III}

General Charles H. Bonesteel III served in the US Army for thirty-eight years. ${ }^{17}$ He was commissioned as a Second Lieutenant Engineer Officer from the US Military Academy in 1931. He retired as a four-star General in 1969 after successfully commanding US Forces Korea. ${ }^{18}$ General Bonesteel served on multiple operational and strategic level staffs and commanded troops up to the Army level. Bonesteel's manager leadership in staff planning and command utilized many operational ways and means to achieving strategic ends. Bonesteel championed the DUKW and the Bailey Bridge, served on the planning staff for the Sicily and Normandy campaigns, helped plan Operations Lucky Strike I and II, participated in Project Solarium, advocated the principle of realistic training, drafted documents supporting the surrender of Japan,

${ }^{16}$ David S. Patterson, Paul Claussen, Evan M. Duncan, Jeffrey A. Soukup, eds., Foreign Relations of the United States, 1961-1963, v. 25: Organization of Foreign Policy; Information Policy; United Nations; Scientific Matters (Washington, DC: Government Printing Office, 2001), 161; Binder, 238.

${ }^{17}$ There is no published biography of Charles H. Bonesteel, III. There is an extensive oral history transcript from the US Army War College’s Senior Officer Oral History Program interviewed by Robert St. Louis. Charles H. Bonesteel, III, “General Charles H. Bonesteel III, US Army Retired,” Interviewed by Lieutenant Colonel Robert St. Louis, US Army, in Arlington, VA, on November 9, 1972, interview Tape B-33 through Tape B-38, transcripts, Volume I; US Army Military History Institute (MHI); 221.01 Permanent Vol. I; HRC 314.82 Bonesteel, Gen. Charles H., III; Senior Officers Oral History Program by the US Army War College - MHI; Project 73-2 (Carlisle Barracks, PA; 17013-5008, 1973), Appendix A, 1.

${ }^{18}$ Bonesteel's time as Commander of USFK is described in Daniel P. Bolger's, Scenes from an Unfinished War: Low Intensity Conflict in Korea, 1966-1969, Leavenworth Papers no 19 (Fort Leavenworth: Combat Studies Institute, 1991); Amos A. Jordan, Jr., Issues of National Security in the 1970s (New York: Frederick A. Praeger Publishers, 1967), 333; Bonesteel, "General Charles H. Bonesteel III, US Army Retired," Appendix A, 1-2. 
and helped draft the Marshall Plan. ${ }^{19}$ Bonesteel’s experiences and manager leadership style ensured the incorporation of ways and means to achieve the desired ends and significantly contributed to the US Army’s understanding of operational art.

\section{Interwar Period}

Lemnitzer’s early military career did not appear exceptional. The US military drastically downsized its World War I personnel numbers and subsequent advancements in promotion rates were slow. The US Army reduced its end-strength at the conclusion of World War I from 2.4 million soldiers to a post-war strength of two-hundred thousand in one year. ${ }^{20}$ Reductions in force size and capability continued for the next fifteen years. ${ }^{21}$ The Coastal Artillery Corps focused on defending the American shores and territories from invaders and was a critical enabler during the period of American isolationism. ${ }^{22}$ World War II marked a transition in mission focus of the Coastal Artillery Corps from defending the American coast to prioritizing its capabilities to antiaircraft artillery fires. ${ }^{23}$ Lemnitzer's initial duty stations after commissioning included Fort

${ }^{19}$ Jordan, Issues of National Security in the 1970s, 333; James F. Schnabel, Policy and Direction the First Year (Washington, DC: Center of Military History, 1992), 9-10; Greg M. Behrman, The Most Noble Adventure: The Marshall Plan and the Time When America Helped Save Europe (New York: Free Press, 2007), 193; Paul R. Porter, "Oral History Interview with Paul R. Porter," interviewed by Richard D. McKinzie and Theodore A. Wilson in Reston, VA on November 30, 1971. Harry S. Truman Library and Museum website, 34-35, accessed March 24, 2015, http://www.trumanlibrary.org/oralhist/porterpr.htm. Expressed how Bonesteel and Lincoln Gordon assisted Averell Harriman in planning the Marshall Plan. While Bonesteel was working on the aforementioned, Paul Porter was Deputy and later Chief, Mission for Economic Affairs, American Embassy, London, 1945-47. Porter's other experience included Chairman, Shipbuilding Stabilization Committee, War Production Board, Washington, 1941-45; Chief, U.S. delegate to the Economic Commission for Europe, Geneva, Switzerland, 1947-49; Chief, Economic Cooperation Administration Mission to Greece, 1949-50; Assistant Administrator, ECA, 1950-51; and Deputy U.S. Special Representative in Europe, Mutual Security Program, Paris, France, 1952-53.

${ }^{20}$ Allan R. Millett, Peter Maslowski, and William B. Feis, For the Common Defense: A Military History of the United States from 1607-2012, 3rd ed. (New York: Free Press, 2012), 344; Binder, 29.

${ }^{21}$ Millett, et al, 341; Binder, 29.

${ }^{22}$ Binder, 35.

${ }^{23}$ Ibid, 37. 
Monroe, Virginia for coastal artillery training followed by an assignment on Corregidor in the Philippine Islands. ${ }^{24}$ Lemnitzer's OER rater score pattern began to transition from ‘average’ to ‘superior’ following Colonel Stanley Embrick’s positive senior rater comments, his contestation of Lemnitzer's mediocre rater scores, and his highlighting of Lemnitzer's planning capabilities. ${ }^{25}$ Corresponding with his improving OER rating scores — and his transfer from the Philippine Islands to the US Military Academy — Lemnitzer's promotion from the rank of Lieutenant to Captain encapsulated fifteen years of service. ${ }^{26}$

Bonesteel's family heritage of military service in the US Army provided him a unique opportunity to interact with senior officers from the beginning of his career forward. He was the fourth generation of his family to graduate from the US Military Academy. Bonesteel's father retired as a Major General, his grandfather fought in the Spanish-American War in 1898, and his great-grandfather earned the Medal of Honor at the Battle of Antietam in 1862 and initiated a family tradition of commissioning from the US Military Academy in $1854 .{ }^{27}$ As such, Bonesteel's name recognition aided his access to senior leaders early in his career.

In Bonesteel's initial years of military service, he was engaged in improving national infrastructure inside the continental United States. Bonesteel was the finance officer on the 1935 Bonneville Dam project across the Columbia River on the Washington and Oregon state

\section{${ }^{24}$ Binder, 40.}

${ }^{25}$ Ibid., 48-49.

${ }^{26}$ William Gardner Bell, Commanding Generals and Chiefs of Staff, 1775-2005: Portraits \& Biographical Sketches (Washington, DC: Government Printing Office, 2010), 136; Binder, 59.

${ }^{27}$ Daniel P. Bolger, Scenes from an Unfinished War: Low Intensity Conflict in Korea, 1966-1969, Leavenworth Papers no 19 (Fort Leavenworth: Combat Studies Institute, 1991), 8; Bonesteel, “General Charles H. Bonesteel III, US Army Retired,” 3-4; D.K.R. Crosswell, Beetle: the Life of General Walter Bedell Smith (Lexington: University Press of Kentucky, 2010), 403. 
boundary from June 1936 to May $1938 .{ }^{28}$ An early example of the Bonesteel family heritage benefitting him occurred during this project. His grandfather's reputation and associations from the Nez Perce Indian War provided Bonesteel with personal contacts with the Governor of Oregon and many of the greater surrounding area's residents. ${ }^{29}$ These relationships and Bonesteel's manager leadership enabled him to talk the labor union representatives into completing the Bonneville Dam project at the negotiated salary contract instead of re-negotiating for higher salaries or leaving an unfinished project if they travelled to areas with greater economic opportunities. ${ }^{30}$ Bonesteel's reputation and leadership facilitated the completion of the Bonneville Dam project. The project was successfully concluded without additional costs or labor disputes.

The US Army Officer Education System that sculpted the manner of many World War II officer’s thinking occurred at Command and General Staff School in Fort Leavenworth, Kansas. Peter J. Schifferle’s, America's School for War: Fort Leavenworth, Officer Education, and Victory in World War II suggests how the lessons learned from World War I shaped the instructional focus at Command and General Staff School in anticipation for the next world war. The three essential courses instructed at Command and General Staff School were problem solving, theories and techniques for fighting corps or division-level and higher formations on the battle field, and classroom practical exercise experience in both the command and staff tasks

${ }^{28}$ Bonesteel, “General Charles H. Bonesteel III, US Army Retired,” 80; Ibid., Appendix A, 3. John W. Barnes, "Engineer Memoirs: MG John W. Barnes, USA, Retired.” Manuscript from tape-recorded interview by Barry W. Fowle at the home of Major General John W. (Jack) Barnes, USA, Retired, at his home in Issaquah, Washington, on 5 April 1995. (Washington, DC: Office of History, US Army Corps of Engineers, 1995), 13, Barnes describes how his father worked for Bonesteel at the Bonneville Dam project.

${ }^{29}$ Bonesteel, “General Charles H. Bonesteel III, US Army Retired,” 81.

${ }^{30}$ Ibid., 84-85. 
necessary for managing these formations in war. ${ }^{31}$ Lemnitzer was a 1936 graduate, but Bonesteel did not attend Command and General Staff School. ${ }^{32}$ The emphasis on teaching both command and staff tasks benefitted the two American Army officers with self-confidence in World War II because Lemnitzer and Bonesteel frequently interchanged between commanding formations and staff positions critical to support commanders when they were not in command. ${ }^{33}$

${ }^{31}$ Peter J. Schifferle, America's School for War: Fort Leavenworth, Officer Education, and Victory in World War II (Lawrence: University Press of Kansas, 2010), 190.

32 Binder, 60; Schifferle, 113.

${ }^{33}$ Schifferle, 190-91. 


\section{Wartime Careers}

Lemnitzer's advancement in rank and responsibility increased significantly following the outbreak of war in Europe in 1939. He advanced to the rank of major, became a battalion commander, and assumed planning responsibility for the $70^{\text {th }}$ Antiaircraft Regiment in $1940 .{ }^{34} \mathrm{By}$ mid-1941, Lemnitzer advanced to the rank of lieutenant colonel and assumed additional responsibility as an assistant operations planner in the War Plans Division of the War Department's General Staff. ${ }^{35}$ He later moved to the Army General Headquarters. ${ }^{36}$ Brigadier General Harry Malony was the superior officer who selected Lemnitzer for advancement into the G-3 planning staff of the Army General Headquarters after Malony observed Lemnitzer’s capabilities while serving in the War Plans Division. ${ }^{37}$ Lemnitzer focused on contingency plans for the defense of Iceland and Azores. ${ }^{38}$ The Azares were Portuguese territories and both were important for securing US shipping lanes to Europe. The importance of the Azores contingency plan helped inform Lemnitzer about an area he would soon have even more important planning responsibilities nearby. The Azores area was geographically close in relationship to the area when Lemnitzer planned support operations for the Allied invasion of North Africa. In 1942, Lemnitzer advanced in rank to brigadier general, assumed brigade command, and then assumed the responsibility as the chief of plans to the Army Ground Forces command when the Army General Headquarters deactivated. ${ }^{39}$ Brigadier General Mark Clark was the chief of staff supervising

\footnotetext{
${ }^{34}$ Binder, 65.

${ }^{35}$ Ibid.

${ }^{36}$ Ibid.
}

${ }^{37}$ Ray S. Cline, United States Army in World War II: The War Department: Washington Command Post: The Operations Division (Washington, DC: Office of the Chief of Military History, Department of the Army, 1951), 329; Binder, 68.

\footnotetext{
${ }^{38}$ Binder, 69.

${ }^{39}$ Ibid., 71.
} 
Lemnitzer in Army Ground Forces command. ${ }^{40}$ Lemnitzer and Clark’s careers had frequent interaction after this time period. Clark, as General Eisenhower's deputy, later requested Lemnitzer as the planning officer for the Allied invasion of North Africa campaign during World War II. ${ }^{41}$

Bonesteel focused on training and resourcing during the initial period of World War II. Realistic training was a principle Bonesteel was deeply committed to. His intent as a manager was to achieve realistic readiness within his troop formations before going onto the battlefield. ${ }^{42}$ One example of realistic readiness was his integration of the British training model into the American training model to prepare new recruits for the fog of warfare during basic training, instead of during their initial engagements with Axis forces. The British trained with live ammunition, TNT, and induced a stressful environment to create a realistic training environment harsher than actual combat so their troops did not learn hard lessons, which frequently resulted in a greater number of unwarranted and unnecessary injuries or deaths while under enemy contact. ${ }^{43}$ Bonesteel contacted General Huebner, Assistant G-3 in the War Department General Staff (also a good friend of his father), to send officers and noncommissioned officers to observe the British training system for incorporation into the American training model. ${ }^{44}$ Huebner's men observed the British training model, but in their reports assessed the British model to be insignificantly different from their American training model. ${ }^{45}$ No changes occurred as a result of the inquiry.

${ }^{40}$ Martin Blumenson, Mark Clark: The Last of the Great World War II Commanders (New York: Congdon and Weed, 1984), 50; Binder, 71.

${ }^{41}$ Blumenson, Mark Clark, 61; Binder, 72. 333.

42 Bonesteel, “General Charles H. Bonesteel III, US Army Retired,” 169; Amos Jordan,

${ }^{43}$ Bonesteel, “General Charles H. Bonesteel III, US Army Retired,” 109.

${ }^{44}$ Ibid., 110.

45 Ibid., 111. 
The American training model was considered more than sufficient as compared to the hardened British training model.

Bonesteel's ability to anticipate critical resource requirements contributed to American topographical understanding of Europe. He supervised the relocation of the British Military Map Library across the Atlantic Ocean to the American Engineer Map Library for security during World War II. ${ }^{46}$ The safeguarding of these maps in America also provided American strategic planners greater access to the extensive British map system, which had evolved into a detailed system due to Britain’s imperial holdings. This critical resource enhanced strategic and operational planners' understanding and visualization of the theaters of war.

Lemnitzer recommendation facilitated the establishment of a unified mission command over Allied forces as the Allied Forces Plans Section chief. The action is important because the previous Allied forces command structure established for General John Pershing’s American Expeditionary Forces (AEF) during World War I had not been unified. ${ }^{47}$ Pershing's command was contested between parallel and amalgamated chains of command, and did not fully integrate commands to their full potential. ${ }^{48}$ Parallel chains of command receive command orders from or approved by the political leader of their country of origin, but not from the senior military commander in theater. ${ }^{49}$ Unit integrity is maintained, however, amalgamated command during World War I placed the American forces into British or French units and subjected them to existing command structures of either foreign country. ${ }^{50}$ The negative aspect of amalgamation is that original unit integrity can be abolished. For example, an American division could be

${ }^{46}$ Bonesteel, “General Charles H. Bonesteel III, US Army Retired,” 101.

${ }^{47}$ Russell Weigley, History of the United States Army (New York: Macmillan, 1967), 381-384; Millett, et al, 325.

${ }^{48}$ Weigley, 381-384; Millett, et al, 325.

49 Joint Publication (JP) 1-02, Department of Defense Dictionary of Military and Associated Terms (Washington, DC: Joint Staff Pentagon, October 2013), 207.

${ }^{50}$ Millet, et al, 325. 
dissolved by amalgamating its soldiers into the ranks of an existing British division as augmentees to fill the ranks. Unified mission command also assists a manager in concentrating his resources at the decisive point on a battlefield by removing the time-consuming coordinations necessary in parallel command structures.

Lemnitzer enabled the establishment of a unified mission command system by bringing to the attention of General Eisenhower a British request which stated British troops inside the Allied Forces Headquarters could appeal to their national chain of command if they did not agree with the Allied chain of command's directives. ${ }^{51}$ The British request effectively created two chains of command, injecting additional friction and generating unnecessary distrust amongst allies. Eisenhower undertook actions to dissolve this request before he would consent to becoming the Supreme Allied Commander in Europe. ${ }^{52}$ Lemnitzer’s initiative unified the military chain of command inside the Allied Forces and subordinated units to the orders of their military commander singularly and not to their national politician’s orders. Additionally, this agreement set the precedent of a singular unified command structure between American and British forces in future conflicts.

Bonesteel similarly established relationships and enhanced his reputation within the Engineer Board on which he served. A position he held during his assignment from July 1938 to September 1941 at Fort Belvoir, Virginia. ${ }^{53}$ Multiple Research and Development (R\&D) concepts presented themselves at this time and in the following years. ${ }^{54}$ Bonesteel — through his professional friendships - helped bring two very important ideas to the European campaign of

${ }^{51}$ Millett, et al, 380; Binder, 72.

${ }^{52}$ Millett, et al, 380; Binder, 72-73.

${ }^{53}$ Bonesteel, “General Charles H. Bonesteel III, US Army Retired,” 86; Ibid., Appendix A, 3.

${ }^{54}$ Bonesteel, “General Charles H. Bonesteel III, US Army Retired,” 86-87. 
Allied forces during World War II. The concepts were the DUKW and the Bailey Bridge. ${ }^{55}$ The DUKW is a General Motors Corporation naming acronym meaning ' $D$ ' designed in 1942, ' $U$ ' utility vehicle, ' $\mathrm{K}$ ' all-wheel drive, and ' $\mathrm{W}$ ' dual rear axles. ${ }^{56}$ The DUKW is a six-wheeled amphibious vehicle that can operate on land or in water. Bonesteel's basketball teammate and fellow West Pointer, Frank S. Besson (head of the Development Board of the Corps of Engineers), introduced him to the idea of utilizing the DUKW in the Sicily campaign due to its effectiveness in the Pacific theater. ${ }^{57}$ The DUKW was particularly effective since it enabled troops to disembark from naval ships while still on the ocean, navigate open water to the beachhead, and drive up on land. ${ }^{58}$ The concentration of combat capable manpower is important to securing beachheads. Bonesteel, as the Acting Chief Engineer planner for Task Force 141 from September 1942 to February 1943, convinced Generals Bedell Smith and Dwight D. Eisenhower to requisition as many DUKWs as possible and establish driver training schools in North Africa in preparation for the Sicily invasion in 1943, named Operation Husky. ${ }^{59}$ Bonesteel took action to

${ }^{55}$ Bonesteel, “General Charles H. Bonesteel III, US Army Retired,” 87-89.

${ }^{56}$ Definition of the DUKW acronym described in Elliott V. Converse III's, Rearming for the Cold War, 1945-1960: History of Acquisition in the Department of Defense, v. 1 (Washington, DC; Historical Office of the Secretary of Defense, 2012), 383-84, accessed February 11, 2015, http://www.dtic.mil/dtic/tr/fulltext/u2/a560470.pdf.

${ }^{57}$ Geoffrey Perret, There's a War to be Won: The United States Army in World War II (New York: Random House, 1991), 182; Crosswell, 403; Bonesteel, "General Charles H. Bonesteel III, US Army Retired,” 88-89. Besson served on the Engineer Board, worked in the Engineer School, Chief of the Railway Commission in Europe and became a general officer during World War II. James Strom Thurmond, Tribute Speech, "Tribute to the Late General Frank S. Besson, Jr.,” United States Senate Floor Session 105-1 (143 Congressional Record Section 7947, Vol. 143 No. 105 S7947, July 23, 1997), accessed February 11, 2015, http://congressional.proquest.com/ congressional/docview/t17.d18.c4b5e48811002966? accountid=28992.

${ }^{58}$ Weigley, 479; Crosswell, 403-404; Bonesteel, “General Charles H. Bonesteel III, US Army Retired," 89-90.

${ }^{59}$ Crosswell, 403; Bonesteel, "General Charles H. Bonesteel III, US Army Retired,” 8990; Ibid., Appendix A, 4. Bedell Smith was also a family friend of his father's tracing back to Fort Benning, Georgia. Crosswell, 403; Bonesteel, "General Charles H. Bonesteel III, US Army Retired,” 134. 
acquire the DUKW for the Sicily campaign because the Mediterranean Sea has geographical sand formations surrounding its islands that prevent naval ships from reaching land except in established port areas, these key areas likely had Axis forces overwatching them and indicated a potential Allied invasion landing site. ${ }^{60}$ Over seven hundred DUKWs were employed as a secret troop transport weapon as a result of Bonesteel's actions during the July invasion of Sicily. ${ }^{61}$ Allied forces were able to successfully land on numerous beaches and relatively unopposed by defensive forces during Operation Husky.

The Bailey Bridge was another critical enabler to successful Allied combat operations. The Bailey Bridge was lightweight enough for tanks to carry due to its construction of metal beams and wooden planks. ${ }^{62}$ Bonesteel worked with Besson to refine the original Bailey Bridge concept and mass-produce it inside the United States for employment in support of the Operation Husky invasion through Sicily into Italy. The Bailey Bridge was considered a secret weapon during the invasion of Europe. ${ }^{63}$ The bridge capabilities exponentially increased the mobility and decentralization of mechanized Allied forces from the restrictive routes which were reliant on established bridge crossing sites known to the Axis forces.

Lemnitzer's actions as the lead Allied planner contributed to the success of the North African invasion, Salerno campaign, and Anzio campaign during World War II. ${ }^{64}$ Lemnitzer conducted a clandestine reconnaissance mission in North Africa which collected vital intelligence

${ }^{60}$ Crosswell, 403; Bonesteel, “General Charles H. Bonesteel III, US Army Retired,” 89.

${ }^{61}$ Omar Bradley, A Soldier’s Story (New York: Modern Library, 1999), 129-130; Bonesteel, “General Charles H. Bonesteel III, US Army Retired,” 89.

${ }^{62}$ Technical Manual (TM) 5-277, Panel Bridge, Bailey Type, M2, Department of the Army Technical Manual (Washington, DC: Government Printing Office, 1986), 2; Bonesteel, “General Charles H. Bonesteel III, US Army Retired,” 100-01.

${ }^{63}$ Brian Harpur, A Bridge to Victory: The Untold Story of the Bailey Bridge (London: H.M. Stationery Office, 1991), 52; Bonesteel, "General Charles H. Bonesteel III, US Army Retired,” 101. 166.

${ }^{64}$ Steven T. Ross, ed., U.S. War Plans, 1938-1945 (Boulder, CO: Lynne Rienner, 2002), 
on anticipated enemy capabilities the invading Allied forces would face. He established a cooperation agreement with leadership of the local French force to assist the American troops in landing unopposed during Operation Torch and to form an alliance in North Africa between the American and the French troops to fight against any Axis forces that appeared after the Torch landing. ${ }^{65}$ Lemnitzer traveled in the Seraph submarine to reach the French Algerian shoreline undetected. ${ }^{66}$ Major General Mark Clark and Brigadier General Lemnitzer accomplished this reconnaissance mission by secretly meeting with French Major General Charles Mast to try and convince Vichy French forces in North Africa to not resist Allied landings; there were no Axis forces within French controlled areas of Morocco, Algeria, and Tunisia based upon a 1940 agreement between France and Nazi Germany. ${ }^{67}$ The 1940 agreement stated that Vichy French forces would defend North Africa from invasion by Axis’ enemies. ${ }^{68}$ Lemnitzer's reconnaissance produced critical information which enabled detailed analysis for the final planning and coordination required for the successful execution of Operation Torch, the Allied invasion of North Africa in November 1942.

Bonesteel was an important staff planner from February 1942 through the completion of World War II who understood how to synchronize the ways and means available to achieve the desired operational end states. ${ }^{69}$ He was the Chief Engineer Planner responsible for ensuring the

65 Binder, 83.

${ }^{66}$ Blumenson, Mark Clark, 78; Great Britain Admiralty, His Majesty’s Submarines, $5^{\text {th }}$ ed. (Bennington, VT: Merriam Press, 2007), 50; Binder, 79.

${ }^{67}$ Robert Rozett and Shmuel Spector, eds., Encyclopedia of the Holocaust (Jerusalem, Israel: Jerusalem Publishing House, 2000), 104; Alan Axelrod, Risk: Adversaries and Allies: Mastering Strategic Relationships (New York: Sterling Publishing, 2009), 111; Blumenson, Mark Clark, 82-84; Binder, 81-82.

${ }^{68}$ Robert Gildea, France Since 1945 (New York: Oxford University Press, 2002), 5; Binder, 82.

${ }^{69}$ Alfred M. Beck, Technical Services, the Corps of Engineers, the War Against Germany (Fort Leavenworth, KS: US Army Center of Military History, 1985), 22; Bonesteel, "General Charles H. Bonesteel III, US Army Retired,” 116; Ibid., Appendix A, 4. 
Allied forces successfully crossed the English Channel to Normandy as the initial phase of the Allied invasion of Europe. ${ }^{70}$ Bonesteel ensured that sufficient concentration of Allied forces occurred on the battlefield in a manner to overwhelm opposing German forces. He then participated in the planning of Operation Lucky Strike I and II. ${ }^{71}$ These operations resulted in the successful mass movement of troops from Great Britain to France without suffering debilitating operational level friendly losses of troops. Allied offensive maneuver operations would then follow into Germany.

Lieutenant General Eisenhower established Fifth Army following Operation Torch, placing his former deputy, Lieutenant General Mark Clark in command. ${ }^{72}$ Clark requested Brigadier General Lemnitzer to serve as his deputy chief of staff in $1943 .{ }^{73}$ Lemnitzer gained his second assignment as a brigade commander. The command was over the same $34^{\text {th }}$ Antiaircraft Brigade he originally commanded prior to his assignment as the Allied Forces Plans Section chief. ${ }^{74}$ Lemnitzer’s brigade fell under Lieutenant General George Patton’s Seventh Army during Operation Husky, the Allied invasion of Sicily that summer. ${ }^{75}$ He relinquished command of the brigade after the landing phase of Operation Husky and transferred to the Allied Fifteenth Army Group. ${ }^{76}$

Brigadier General Lemnitzer assumed the position of deputy chief of staff for British General, Sir Harold Rupert Leofric George Alexander, as part of the Allied Fifteenth Army

${ }^{70}$ Bonesteel, “General Charles H. Bonesteel III, US Army Retired,” 122; Appendix A, 4.

${ }^{71}$ Ibid., 137.

${ }^{72}$ Millett, et al, 403; Binder, 102.

${ }^{73}$ Millett, et al, 403; Binder, 102-103, Lemnitzer served in Fifth Army for six weeks before transferring to Seventh Army to command the $34^{\text {th }}$ Antiaircraft Brigade.

${ }^{74}$ Binder, 103.

${ }^{75}$ Ibid., 104.

${ }^{76}$ Rupert Clarke, With Alex at War: From the Irrawaddy to the Po, 1941-1945 (South Yorks, Great Britain: Leo Cooper, 2000), 47; Binder, 104. 
Group in $1943 .{ }^{77}$ General Alexander's Allied Fifteenth Army Group primarily consisted of Lieutenant General George Patton’s American Seventh Army and General Bernard Montgomery’s British Eighth Army during the Sicily campaign. ${ }^{78}$ Lemnitzer’s contributions to the success of the Allied war effort included building international coalition relationships, planning the Salerno and Anzio invasions, and facilitating the surrender of German troops in Italy. General Alexander believed Lemnitzer's actions as the deputy chief of staff strengthened the relationship between American and British military staff. ${ }^{79}$ Strengthening the relationship between American and British officers was important because each country’s institutional military leadership development program was fundamentally different. The American military system and culture rested responsibility on the commander for making decisions and planning operations, whilst the British system rested responsibility on the commander's staff to plan in a collective methodology to accomplish the commander's decisions. ${ }^{80}$ Many of these allied interactions occurred during Lemnitzer's planning of the Salerno and Anzio invasion operations after the Sicily campaign. ${ }^{81}$ One of the significant initial challenges he faced was the low opinion held by the British and French military of the American military's capabilities as the newest country to the Allied war effort. ${ }^{82}$ The American troops' abysmal performance in initial North

${ }^{77}$ Clarke, 47; Binder, 106.

${ }^{78}$ Millett, et al, 402; Binder, 110; Clarke, $99.15^{\text {th }}$ Army Group originally made up of US $7^{\text {th }}$ Army and UK $8^{\text {th }}$ Army $(7+8=15)$, but after Operation Husky it was composed of US $5^{\text {th }}$ Army and UK $8^{\text {th }}$ Army. Numbered naming conventions for Army Groups were derived from totaling the subordinate Army numbers within the Group. People apprehensive of the number 13 $(5+8=13)$ likely worked to continue calling it the $15^{\text {th }}$ Army Group to avoid calling it the $13^{\text {th }}$ Army Group.

${ }^{79}$ Clarke, 227; Binder, 112.

${ }^{80}$ Rose, 46; Clarke, 103.

${ }^{81}$ Martin Blumenson, United States Army in World War 2, Mediterranean Theater of Operations: Salerno to Cassino (Washington, DC: Office of the Chief of Military History, 1969), 301; Binder, 115, 117.

${ }^{82}$ Clarke, 87; Binder, 109. 
African battles also contributed to the poor opinion of American forces. ${ }^{83}$ General Patton's impressive tactics in the Sicily campaign — coupled with General Eisenhower's order to General Alexander to re-mission Patton's Army from a supporting role to a leading role — and Lemnitzer's ability to function cooperatively with the British leadership enhanced this perception. ${ }^{84}$ Patton's Seventh Army reached the final Allied objective of Messina in the Sicily campaign before the planned and intended force of General Montgomery. ${ }^{85}$ Patton's performance contributed to increased Allied respect of American military capability. ${ }^{86}$ Lemnitzer's superior role in staff planning operations, cooperating with fellow Allied planners, and negotiating the surrender enabled the linkage of the tactical actions on the ground to the accomplishment of the strategic Allied objectives.

Lemnitzer advanced to the rank of major general in June 1944 after the completion of the Anzio invasion. ${ }^{87}$ British General Alexander was promoted to the rank of field marshal and given the responsibility of supreme allied command over the Mediterranean theater of operations in December $1944 .^{88}$ General Eisenhower transferred out of theater earlier in the year to plan Operation Overlord, the invasion of Europe from Britain. Colonel Bonesteel was part of this planning staff. ${ }^{89}$

Lemnitzer's role in negotiating the surrender of German troops operating in Italy was integral to achieving the surrender of the Axis forces in the European theater. Major General

${ }^{83}$ Clarke, 84; Binder, 109.

${ }^{84}$ Clarke, 119; Binder, 109.

${ }^{85}$ Dupuy and Dupuy, 1095; Clarke, 115; Binder, 110.

${ }^{86}$ Clarke, 119; Binder, 110.

${ }^{87}$ Binder, 128.

${ }^{88}$ Clarke, 183; Binder, 106.

${ }^{89}$ George Smith Patton, Jr. and Paul D. Harkins, War as I Knew It (Boston: Houghton Mifflin, 1947), 171; Binder, 117. 
Lemnitzer and British Major General Terence Airey were covertly transported into Switzerland to meet with senior German military officers interested in ending World War II. ${ }^{90}$ Allen Dulles, of the Officer of Strategic Services (OSS) and later the head of the Central Intelligence Agency, facilitated the Switzerland meeting location and the necessary processes to bring both generals covertly to the negotiation site. ${ }^{91}$

Major General Lemnitzer’s German counterpart, General Karl Wolff commanded the Schutzstaffel troops in Italy — more commonly known as the SS troops — and was the principal senior officer negotiating the German surrender with Lemnitzer and Airey. ${ }^{92}$ Field Marshal Albert Kesselring commanded German conventional forces in Italy, and while not present at the meetings, the participants believed him to have a similar mindset as Wolff, that Germany was defeated and surrender was the appropriate course of action. ${ }^{93}$ Lemnitzer's chief tactic in the negotiation was limiting the terms of the dialogue to an unconditional military surrender of all German forces in Italy while not addressing political, economic, or any other aspects the Germans attempted to bring into the negotiation. ${ }^{94}$ This occurred to ensure speed and simplicity in the military surrender negotiation process while preventing the complexity of diplomatic or economic issues from slowing the process.

The German surrender process stalled when Schutzstaffel Chief Heinrich Himmler summoned Wolff back to Germany to question him on his suspicions of Wolff's recent

${ }^{90}$ Kerstin von Lingen, Allen Dulles, the OSS, and Nazi War Criminals: The Dynamics of Selective Prosecution (New York: Cambridge University Press, 2013), 70; Kaplan, 145; Binder, 135.

${ }^{91}$ Lingen, 67; Poole, 97; Binder, 134; Kaplan, 145.

${ }_{92}$ Michael Salter, Nazi War Crimes, US Intelligence and Selective Prosecution at Nuremberg: Controversies Regarding the Role of the Office of Strategic Services (New York: Routledge-Cavendish, 2007), 122; Lingen, 64; Binder, 134.

${ }^{93}$ Dupuy and Dupuy, 1096; Binder, 134.

${ }^{94}$ Binder, 138. 
activities. ${ }^{95}$ Wolff met with Adolph Hitler during this summons to explain he had worked to find a method to connect Hitler with the political leadership of the American and British forces if Hitler considered the possibility of a German surrender in the future. ${ }^{96}$ During the period of suspended negotiations, two important military actions occurred. First, General Heinrich Vietinghoff replaced Field Marshal Kesselring as commander of German conventional forces in Italy. ${ }^{97}$ Secondly, Field Marshal Alexander began offensive operations against the Axis forces in Italy with his Fifth and Eighth Armies. ${ }^{98}$ The results were two-fold. Lemnitzer and Wolff now had a new commander of conventional German forces in Italy to convince that a speedy and unconditional military surrender was the best decision. Additional losses of German forces to Field Marshall Alexander’s Army strengthened Lemnitzer’s negotiation position.

Lemnitzer again demonstrated his talent as an operational artist at this point. The Soviet Union pressured American and British officials to give them a role in covert negotiations for the surrender of German troops in Italy. ${ }^{99}$ When Lemnitzer learned of the Soviet's desire, he based his calculated response on Soviet standard negotiations, a negotiator, and a political officer. ${ }^{100}$ The Soviet presence was limited to the parameter of one man who spoke English so as not to make the covert negotiation footprint large and noticeable. ${ }^{101}$ Lemnitzer anticipated the likely conflict this would create regarding the Soviet standing operating procedure for sending a political representative to oversee the actions of their military officers. ${ }^{102}$ Lemnitzer's deftly

\footnotetext{
${ }^{95}$ Lingen, 71; Binder, 139-40.

${ }^{96}$ Lingen, 72; Binder, 140.

${ }^{97}$ Lingen, 71; Dupuy and Dupuy, 1118; Binder, 138.

${ }^{98}$ Lingen, 71; Binder, 139.

${ }^{99}$ Lingen, 68; Binder, 141.

${ }^{100}$ Salter, 155; Binder, 142.

${ }^{101}$ Salter, 155; Binder, 142.

102 Binder, 142.
} 
calculated decision at the tactical level to limit Soviet attendance at the covert negotiations to one representative who spoke English, produced the desired effect when the Soviets did not send a representative. This enabled the American and British leaders at the strategic level to achieve their objective of maintaining a relationship with the Soviets while empowering the Soviets to deselect themselves from becoming engaged in the surrender negotiations. American and British leadership did not want the Soviets involved in the surrender negotiation, as they believed the Soviets were purely interested in becoming stakeholders to gain control of Northern Italy and the port of Trieste for access to the Mediterranean Sea. ${ }^{103}$ In late April, the surrender negotiations resumed as Wolff and Vietinghoff's representatives who had diplomatic authority to act on behalf of their state met with Lemnitzer to finalize the unconditional surrender of German troops in Italy in May of $1945 .{ }^{104}$ The results of Lemnitzer's actions at the negotiation table were integral to achieving an unconditional surrender of the German troops across Europe without Soviet interference. Once again Lemnitzer facilitated the accomplishment of a strategic objective through tactical action with the surrender of German troops in Italy.

Colonel Bonesteel worked in the Operations and Plans Division on the War Department General Staff at this time (along with fellow Colonel and future Secretary of State Dean Rusk) and from October 1944 to May 1948. ${ }^{105}$ Bonesteel planned the Japanese conditional surrender. He astutely anticipated the surrender to be different from the German unconditional surrender

${ }^{103}$ Salter, 154; Lingen, 75; Binder, 141.

${ }^{104}$ Lingen, 77; Binder, 142-43.

${ }^{105}$ Ronald H. Spector, In the Ruins of Empire: The Japanese Surrender and the Battle for Post War Asia (New York: Random House, 2007), 139; Bonesteel, "General Charles H. Bonesteel III, US Army Retired,” 179; Ibid., Appendix A, 3-4. Robert J. Donovan, Conflict and Crisis: The Presidency of Harry S. Truman, 1945-1948 (Columbia: University of Missouri Press, 1996), 103. 
based upon his knowledge and understanding of their cultural differences. ${ }^{106}$ Bonesteel challenged the State Department's implementation of the presidential policy which called for an unconditional surrender because his intuition and astute understanding of the Japanese culture and the military sub-culture of the Japanese Army would not lay down their arms unless their Emperor directly ordered their surrender. ${ }^{107}$ Conditional surrender through the Japanese emperor was the only culturally effective way to achieving the strategic objective of long lasting peace.

${ }^{106}$ Dale M. Hellegers, We the Japanese People: World War II and the Origins of the Japanese Constitution (Redwood City, CA: Stanford University Press, 2001), 116; Bonesteel, “General Charles H. Bonesteel III, US Army Retired,” 180.

${ }^{107}$ Hellegers, 115; Bonesteel, “General Charles H. Bonesteel III, US Army Retired,” 179. 


\section{Post-War Period}

In the two years following the end of the Second World War in 1945, the US Army decreased from over eight million to seven-hundred thousand men. ${ }^{108}$ American public opinion desired a swift demobilization, while the War Department desired a gradual demobilization due to apprehension of the Soviet Union actions and their vocal desires to expand their ideological areas of control and influence. ${ }^{109}$ The War Department structured a points system based upon the length and difficulty of a soldier's tour to facilitate the gradual downsizing of the military. ${ }^{110}$ The points system was overwhelmed by public outcry. ${ }^{111}$ The public clamor so great that all men with over two years of service were discharged from the services. ${ }^{112}$ Associated with the decrease in American military personnel numbers, the number of army divisions dwindled from ninety-one in 1945 to ten in 1948, while parallel reductions took place in the Army Air Force, the Navy, and the Marine Corps. ${ }^{113}$ Post-World War II reductions in army manpower numbers reflected similar historical patterns of the post-World War I reductions which Lemnizter had initially experienced at the beginning of his military service.

Post-World War II politics and policies denoted a new role for the United States in international affairs. The United States' foreign and defense policies transformed from a posture of isolation with free market capitalism to a reliance on maritime security and wartime mobilization with free market capitalism. ${ }^{114}$ Briefly enjoying a nuclear monopoly, the policy of

${ }^{108}$ Richard F. Haynes, The Awesome Power: Harry S. Truman as Commander in Chief (Baton Rouge: Louisiana State University Press, 1973), 119; Binder, 152.

${ }^{109}$ Weigley, 486; Haynes, 119.

${ }^{110}$ Weigley, 486; Haynes, 116.

111 Weigley, 486; Haynes, 118.

112 Weigley, 486; Haynes, 118.

${ }^{113}$ Weigley, 502; Binder, 153.

${ }^{114}$ Millett, et al, 440; Weigley, 497-98. 
deterrence was adopted to prevent another World War from occurring and enable the American population to enjoy the benefits of winning World War II with a hard earned peace. ${ }^{115}$ The United States invested in the United Nations as a collective defense measure in 1945 and for executing nonnuclear deterrence measures with its regional military alliances established in $1947 .{ }^{116}$ President Truman established the Truman Doctrine in 1947 after granting Greece and Turkey a \$400 million aid package to assist them in preventing Soviet communist activists from gaining control of their governments and territories and promised American assistance to any other nations desiring protection of their territorial sovereignty from similar threats. ${ }^{117}$

Bonesteel helped facilitate the linkage of strategic and operational objectives at the conclusion of World War II where he would influence post-war reconstruction and strategic policy. Bonesteel was the Chief of the Strategic Policy Section in 1945 with the parallel post-war purpose of rebuilding the Japanese economy, similar to the later Marshall Plan for Europe. ${ }^{118}$ Colonel Bonesteel worked under Secretary of State George Marshall from June 1947 to June 1948 to draft the Marshall Plan to rebuild post-war European economies. ${ }^{119}$ He then assisted Ambassador Averell Harriman in Paris with his responsibilities as Chief of the Marshall Plan in

${ }^{115}$ Ingo Trauschweizer, The Cold War U.S. Army: Building Deterrence for Limited War (Lawrence: The University Press of Kansas, 2008), 2; Millett, et al, 441.

116 Nigel D. White, The United Nations System: Towards International Justice (Boulder, CO: Lynne Rienner, 2002), 139-40; Millett, et al, 441.

${ }^{117}$ Michael H. Cosgrove, The Cost of Winning: Global Development Policies and Broken Social Contracts (New Brunswick, NJ: Transaction Publishers, 1996), 37; Millett et al, 442-43.

${ }^{118}$ Cline, 329; Bonesteel, “General Charles H. Bonesteel III, US Army Retired,” 187-88.

${ }^{119}$ Amos Jordan, 333; Bonesteel, “General Charles H. Bonesteel III, US Army Retired,” 197-98; Ibid., Appendix A, 4; Millett, et al, 442-43. 
Europe until 1950. ${ }^{120}$ Building economies in Europe was seen as a way to prevent another radical leader's rise to power like Hitler. Bonesteel's work as a staff officer with the Japanese surrender and reconstruction as well as his participation in development and execution of the Marshall Plan left a definitive 'finger print' on influential strategy.

Lemnitzer was instrumental in building of the North Atlantic Treaty Organization and the alliance concept of military assistance in the late 1940s. The Secretary of Defense, James Forrestal, assigned Lemnitzer the covert mission of attending meetings with the Brussels Pact Military Committee of the Five Powers - Britain, France, Belgium, the Netherlands, and Luxembourg — because of the increasing perceived threat of the Soviet Union attempting to

${ }^{120}$ Behrman, 193; Bonesteel, “General Charles H. Bonesteel III, US Army Retired,” Appendix A, 1; W. Averell Harriman, “Oral History Interview with W. Averell Harriman,” interviewed by Richard D. McKinzie and Theodore A. Wilson, Washington, DC: 1971. Harry S. Truman Library and Museum, 5-6, accessed March 24, 2015, http://www.trumanlibrary.org/ oralhist/harriman.htm\#16. Harriman's experiences included serving the Truman administration as U.S. Ambassador to Russia, 1943-46, to Great Britain, Apr.-Oct. 1946; Secretary of Commerce, Oct. 1946-Apr. 1948; U.S. representative in Europe under the Economic Cooperation Act of 1948, with rank of Ambassador Extraordinary and Plenipotentiary, 1948-50; special assistant to the President, 1950-51; American representative on North Atlantic Treaty Organization Committee to study Western defense plans, 1951; and director of the Mutual Security Agency, 1951-53. See also, Clifford C. Matlock, "Second Oral History Interview with Clifford C. Matlock," interviewed by Richard D. McKinzie in Waynesville, NC on June 6, 1974. Harry S. Truman Library and Museum, 49-50, accessed March 24, 2015, http://www.trumanlibrary.org/ oralhist/matlock.htm. Matlock discussed how Averell Harriman requested Bonesteel to become his Executive Director while Matlock was the political adviser, European Coordinating Committee, London, 1949-50. Matlock’s World War II and post-World War II experiences also included Economist and administrator, Board of Economic Warfare, Foreign Economic Administration, 1942-45; economist and political officer, U.S. Dept. of State, 1946-62; political officer, U.S. delegation North Atlantic Council, London, 1949-50; and political officer and later director of plans and policy staff, Office of U.S. Special Representative in Europe, Paris, 195253. Millett, et al, 442; before NATO, Britain, France, Belgium, Luxembourg, and the Netherlands had formed the Brussels Pact (Treaty of Brussels) in the spring of 1948. 
communize Europe by force. ${ }^{121}$ When Czechoslovakia fell to communism in 1948, the Five Powers signed an alliance known as the Western Union with the concept of each member providing military assistance for another if their state was threatened. ${ }^{122}$ The Western Union would expand in membership and eventually became known as the North Atlantic Treaty Organization (NATO) over time. ${ }^{123}$ Lemnitzer’s secret negotiations and personal relationships within the Western Union states combined with his coordination through the American legislative process over the purpose, requirements, and authorities of the alliance concept for military assistance were a useful contribution to the development of the North Atlantic Treaty Organization. ${ }^{124}$ Lemnitzer's ability to reach consensuses for providing and combining military equipment and defensive capabilities within the alliance at the tactical level enabled the achievement of the strategic objective for protecting states from the spread of communism while minimizing the negative impact of downsizing defense budgets.

${ }^{121}$ Binder, 158; Kaplan, 145; Kathleen Frances Anne Kellner, "Broker of Power: General Lyman L. Lemnitzer,” (PhD diss., Kent State University, 1987), preface. See also, John H. Ohly, “Oral History Interview with John H. Ohly," interviewed by Richard D. McKenzie and Theodore A. Wilson in McLean, VA on November 30, 1971. Harry S. Truman Library and Museum website, 26-27, accessed March 24, 2015, http://www.trumanlibrary.org/oralhist/ohly.htm\#27. Ohly was Special Assistant to the Secretary of Defense from 1947-49, when Lemnitzer was chosen to represent the Secretary of Defense in late 1948 to attend the Western Union meetings. Ohly's experiences additionally included Attorney in the Office of Assistant Secretary of War, 1940-46, later specializing in labor relations, manpower and related matters in the Office of the Under Secretary of War and later in the Army Service Forces; Special Assistant to the Secretary of War, 1946; Executive Secretary to the President's Advisory Commission on Universal Training, 1946-47; Deputy Director, Mutual. Defense Assistance Program, Dept. of State, 194950; Acting Director, Mutual Defense Assistance Program, Dept. of State, 1950; Assistant Director, Office of International Security Affairs, Department of State, 1951; Special Assistant for Mutual Security Affairs in the Office of the Secretary of State, 1951-52; and Assistant Director for Program, Office of the Director for Mutual Security, 1952-53.

${ }^{122}$ Kaplan, 213; Binder, 159, America did not join the Western Union, which later changed its name to the Western European Union, but explored options to create another alliance with the Western Union and North Atlantic countries.

${ }^{123}$ Kaplan, 156; Kellner, preface; Binder, 164.

${ }^{124}$ Kaplan, 146; Kellner, preface; Binder, 162-63. 
The Korean War illustrated to the American government the strategic necessity for a larger standing and reserve military force structure. ${ }^{125}$ Universal military training, a post-World War II concept for mandatory military training and universal reserve service for all American males at eighteen years of age, passed through Congress as the Universal Military Training and Service Act of $1951 .{ }^{126}$ The Congressional action served as a viable option to be utilized in times of a national necessity as a draft, but was never implemented in practice to achieve universal military training within the American male population. ${ }^{127}$ This reflected an open political reliance on the draft in times of war and not a belief in a requirement for genuine universal military service or training for all American males. The Armed Forces Reserve Act of 1952 created three categories of military reserve service duty — Ready Reserve, Standby Reserve, and Retired Reserve - for males between eighteen and a half to twenty-six years of age to belong to, those who had served in the military or had been selected by the Universal Military Training and Service Act of 1951 for military training. ${ }^{128}$ This system enabled the active duty military to remain small during times of peace and effectively expand during times of war. From 1950 and the beginning of the Korean War through 1961 the US Army mobilized over 2.8 million men and twenty divisions to fight in Korea and maintain security in America under the ominous threat felt from the Soviet Union. ${ }^{129}$ The Selective Service Act of 1948 granted the president the authority to activate Reserve and National Guard units to federal service and was the basis for activating eight National Guard divisions for deployment to the Korean War or continental training and

${ }^{125}$ Millett, et al, 463; Weigley, 526.

${ }^{126}$ Weigley, 498-500; Millett et al, 464.

${ }^{127}$ Weigley, 500; Millett et al, 464.

${ }^{128}$ Gerald T. Cantwell, Citizen Airmen: A History of the Air Force Reserve, 1946-1994 (Washington, DC: Government Printing Office, 1997), 125; Weigley, 530.

${ }^{129}$ Weigley, 508. 
security. ${ }^{130}$ Reserve and National Guard forces were relied upon to reinforce the reduced active duty Army numbers following the Second World War.

Lemnitzer and Bonesteel’s professionalism and skill sets had been identified by many senior leaders. President Eisenhower selected both officers to be part of the 1953 Project Solarium, which provided strategic analysis for three proposed methods to defeat or contain communism. ${ }^{131}$ Similar in nature to the rational that brought the Five Powers together (leading to the formation of North Atlantic Treaty Organization), the purpose of Project Solarium was to study and analyze different approaches to prevent the Soviet Union from spreading the communist ideology to other states through coercion or force. The United States defense policy of deterrence began to transition to the containment of the spread of communism when the North Korean People’s Army (NKPA) crossed the 38th Parallel in the summer of 1950 in an attempt to forcibly unify the Korean Peninsula through conquest. ${ }^{132}$ Project Solarium consisted of three groups directed to prepare American foreign policy against communism that focused on containment, roll back, or drawing the line. ${ }^{133}$ The general intent was for each group to analyze and articulate why their plan was the best policy. The following three plans were analyzed: containment, which restricted the Soviet Union from expanding communism to additional states with the threat of war from North Atlantic Treaty Organization powers; to roll back, which utilized covert offensive operations to degrade the existence of communism outside of the Soviet

${ }^{130}$ Stanley Sandler, ed., The Korean War: An Encyclopedia (New York: Routledge, 1995), 298; Weigley, 508-09.

${ }^{131}$ Bowie and Immerman, 122; Binder, 197; Craig Berryman, “The Search for a Cold War Grand Strategy: NSC 68 \& 162,” (master’s thesis, School of Advanced Military Studies, United States Army Command and General Staff College, Fort Leavenworth, Kansas, May 22, 2014), 46, accessed February 11, 2015, http://cgsc.contentdm.oclc.org/utils/getdownloaditem/ collection/p4013coll3/id/3192/filename/3193.pdf/mapsto/pdf/type/singleitem.

132 Millett, et al, 453; Lauren Holland, Weapons Under Fire (New York: Routledge, 1997), 31-32.

133 Bowie and Immerman, 124; Berryman, 37-38; Binder, 197. 
Union proper; and finally to declaring a red-line to the world and communists, which America would meet and repel any efforts to expand communism with a nuclear strike. ${ }^{134}$ Lieutenant General Lemnitzer and Colonel Andrew J. Goodpaster — who succeeded Lemnitzer as the Supreme Allied Commander Europe (SACEUR) in the 1960s decade — energetically participated in the roll back group’s plan. ${ }^{135}$ Colonel Bonesteel actively contributed to George Kennan's concept for the containment of communism group plan that resulted in Eisenhower's national foreign policy stating containment as the main effort and drawing the line as the supporting effort with the military force option always on the table. ${ }^{136}$ The American defense policy resulting from Project Solarium analysis reflected a change in military strategy from one of national crisis response and mobilization to one of alliances designed to persevere and forcibly respond economically and militarily over the attempted territorial expansion of communism. ${ }^{137}$ National circumstances surrounding the Solarium task force was influenced by the nation's preceding three years of active American fighting in the Korean War, President Eisenhower's budget reduction of annual military spending by five billion dollars from President Truman's budget, and the escalation of the Cold War. ${ }^{138}$ Lemnitzer and Bonesteel's insights and contributions to Project Solarium produced results which linked operational actions of concentrating national resources to the accomplishment of the strategic objective of defeating communism.

${ }^{134}$ Berryman, 37-38; Binder, 197; Bowie and Immerman, 124.

135 Trauschweizer, 136; Berryman, 44-45.

136 Trauschweizer, 24; Binder, 198; Bonesteel, “General Charles H. Bonesteel III, US Army Retired,” 208.

${ }^{137}$ Ronald R. Krebs, Dueling Visions: U.S. Strategy toward Eastern Europe under Eisenhower (College Station, TX: Texas A \& M University Press, 2001), 55-56; Millett, et al, 475.

${ }^{138}$ Linn, 164-65; Reardon, 147; Binder, 197. 
Bonesteel served as a Department of Defense Member of the National Security Council Planning Board from June 1953 to June $1956 .{ }^{139}$ During this period, the outcomes from Project Solarium were articulated into NCS 162/2, basic US National Security Policy. ${ }^{140}$ Nomination letters for Bonesteel between senior Eisenhower administration officials to serve on the Planning Board of the National Security Council — including from President Dwight D. Eisenhower and Secretary of Defense Charles E. Wilson — spoke very highly of his outstanding performance in his past duties. ${ }^{141}$ NSC 162/2 was President Eisenhower's New Look plan for national security to contain the Soviet threats with diplomatic, economic, and military actions. ${ }^{142}$ The two overarching approaches of NSC 162/2 involved rebuilding economic strength, maintaining a strong nuclear deterrent, and exploring other initiatives to counter communist expansion. ${ }^{143}$ Bonesteel began incorporating representation from each of the three military services in his planning. ${ }^{144}$ Before this, only one Department of Defense representative had spoken for all branches of the military at the National Security Council Planning Board. ${ }^{145}$ Bonesteel’s

${ }^{139}$ West Point Association of Graduates, Assembly Magazine 28-29 (1969): 39; Berryman, 49; Bonesteel, “General Charles H. Bonesteel III, US Army Retired,” 207-08; Ibid, Appendix A, 5.

${ }^{140}$ Berryman, 36, 74, 78, 80; Bowie and Immerman, 138-39.

${ }^{141}$ Frank C. Nash, Memorandum for the Executive Secretary to National Security Council, Designation of Board Assistants, the Assistant Secretary of Defense, September 22, 1953, White House Office, National Security Council Staff Papers, Disaster File, Box 2, Dwight D. Eisenhower Library; C.E. Wilson to President Eisenhower, Brigadier General Bonesteel Letter of Recommendation to President Eisenhower, February 2, 1956, White House Office, National Security Council Staff Papers, Disaster File, Box 2, Dwight D. Eisenhower Library; Dwight D. Eisenhower to General Bonesteel, Letter to Brigadier General Bonesteel, February 6, 1956, White House Office, National Security Council Staff Papers, Disaster File, Box 2, Dwight D.

Eisenhower Library.

142 Krebs, 51; Trauschweizer, 29.

${ }^{143}$ Bowie and Immerman, 188-89; Trauschweizer, 29.

${ }^{144}$ Bonesteel, “General Charles H. Bonesteel III, US Army Retired,” 239; Ibid., Appendix A, 5.

145 Ibid., 239. 
leadership changed this practice with his pre-meeting coordination meetings with representatives from the Army, Navy, and Air Force to gain realistic feedback on what policies they could or could not support with their operational capabilities per branch. ${ }^{146}$ Realistic feedback by the three service branches better enabled the National Security Council Planning Board to formulate and modify strategic policy by presenting options that were considered unified, feasible, acceptable, and suitable by all branches of the defense department instead of uncoordinated independent service concepts.

President Eisenhower's yearly efforts to reduce the defense budget continued to affect Lemnitzer and Bonesteel. The lack of public support behind American involvement in the Korean War helped Eisenhower in his 1952 political campaign platform where he called for an end to the war. ${ }^{147}$ From 1953 forward, the Eisenhower defense policy was oriented toward deterrence instead of the availability of conventional forces to deploy. ${ }^{148}$ Eisenhower's 'New Look' budgets in the 1950s decreased the Army's personnel numbers from their Korean War peak of 1,596,000 to 873,000 by the end of the decade. ${ }^{149}$ To put this in context, the defense budget did not increase until the Kennedy administration allocated $\$ 20$ billion in increased defense budget spending to the general-purpose ground forces in the military between 1961 and $1964 .^{150}$

Lemnitzer believed the size of the Army was at risk in the 1950s with the prioritization on American air capability and diminishing investment in general-purpose forces. ${ }^{151}$ Reducing the

${ }^{146}$ Gordon, 289; Bonesteel, “General Charles H. Bonesteel III, US Army Retired,” 240.

${ }^{147}$ Weigley, 525.

148 Tom Wicker, Dwight D. Eisenhower: The American Presidents Series: the $34^{\text {th }}$ President (New York: Times Books, 2002), 30; Trauschweizer, 2.

${ }^{149}$ Historical Office, Office of the Secretary of Defense, Department of Defense Key Officials, 1947-2004 (Washington, DC: Office of the Secretary of Defense, Historical Office, 2004), 90; Binder, 233; Millett, et al, 479.

150 Trauschweizer, 123.

151 Trauschweizer, 32; Binder, 202. 
number of soldiers in the Army reduced the defense budget requirements. The expansion of the US Air Force Strategic Air Command was a central focus to the development of a US deterrent capability to mitigate the Soviet threat and was achieved by maintaining options to effectively employ nuclear weapons. ${ }^{152}$ The threat of nuclear weapons via airpower became a method to deter the spread of communism instead of defending territory from communist insurgencies with American conventional forces. ${ }^{153}$ Eisenhower's ‘New Look’ placed primary reliance on nuclear weapons as a deterrent to general war with the Soviet Union. ${ }^{154}$ The US Army was never comfortable with the 'New Look' and struggled throughout the 1950s to articulate the utility of limited force in the nuclear age.

Lemnitzer reduced requirements to provide American military defense forces to South Korea and Japan while he was the commander in chief of the Far East Command. ${ }^{155}$ In 1955 , Lemnitzer was promoted to General and donned several leadership hats simultaneously as the commanding general of US Forces Korea, the Eighth Army, the Far East Command, and the United Nations Command. ${ }^{156}$ His roles and responsibilities were many, but the critical role Lemnitzer played resided in his relationships and interactions with the South Korean President Syngman Rhee. The relationship was critical in establishing and enhancing the independence of

152 Binder, 234.

${ }^{153}$ Wicker, 30; Trauschweizer, 18.

${ }^{154}$ Weigley, 526; Millett, et al, 441; Kenneth Alan Osgood, Total Cold War: Eisenhower's Secret Propaganda Battle at Home and Abroad (Lawrence: University Press of Kansas, 2006), 72; John Lewis Gaddis, Strategies of Containment: A Critical Appraisal of Postwar American National Security Policy (Oxford: Oxford University Press, 1982), 132-33; Berryman, 36. 'Massive retaliation' was characterized by Eisenhower's detractors as the only national security policy for containing the spread of communism by the Soviet Union, but other historians, such as Osgood, Gaddis, and Berryman, have found Eisenhower's 'New Look' strategy contained every ways and means available — to include diplomatic, informational, military, and economic instruments of national power - to achieve national security.

155 Binder, 208.

${ }^{156}$ Ibid., 204, 208. 
the South Korean government's ability to defend South Korea and reducing the American military requirement to do the same. Lemnitzer did this by building upon his rapport with Rhee. ${ }^{157}$ Lemnitzer used these relationships and experiences to design a plan to build and enhance the Republic of Korea's (ROK) defense force capability with American equipment and training while incrementally decreasing the presence of American troops stationed in South Korea. ${ }^{158}$ This plan was similar to the Japanese "National Defense Force” for internal defense that had grown in strength to two-hundred thousand men during Lemnitzer's time as commander in chief of the Far East Command. ${ }^{159}$

The training Exercise Sagebrush was conducted in 1955 at the Fort Polk, Louisiana maneuver area to demonstrate the efficiency of a proposed atomic organization structure the military services were considering for the future. ${ }^{160}$ General Lemnitzer shared the lessons learned from Exercise Sagebrush with South Korean President Syngmun Rhee to continue empowering the Republic of Korea defense forces. ${ }^{161}$ The amount of money, personnel, and time devoted to Sagebrush did not produce the intended results of demonstrating the proposed atomic organization's efficiencies, but demonstrated its inefficiencies instead. ${ }^{162}$ The inefficiencies illuminated included decreased firepower, mobility, communications, and increased existing

${ }^{157}$ Binder, 222.

158 Ibid.

159 John Swenson-Wright, Unequal Allies?: United States Security and Alliance Policy Towards Japan, 1945-1960 (Stanford, CA: Stanford University Press, 2005), 197-98; Binder, 214.

${ }^{160}$ Linn, 175; James W. Williams, A History of Army Aviation: From its Beginnings to the War on Terror (Bloomington, IN: iUniverse, 2005), 70-71.

161 Binder, 208, 204. The lessons was that the increased firepower of US forces would allow a reduction in US forces stationed in South Korea without decreasing deterrent capability of the forces that remained.

162 Linn, 175; Williams, 72. 
Army-to-Air Force tensions, in the current organization structure. ${ }^{163}$ Additionally, the proposed atomic organization structure illustrated the dependence on atomic weapons due to its reliance on the employment of tactical nuclear weapons to destroy invading Soviet military divisions. ${ }^{164}$ This structure was fundamentally and doctrinally flawed because most North Atlantic Treaty Organization countries would not likely agree to the deployment of nuclear munitions on their soil due to the damages forecasted by detonating nuclear weapons. ${ }^{165}$ The intent for the introduction of the 280-mm atomic cannon in 1953 was to enable the tactical and operational distribution of friendly forces across large areas of terrain while maintaining the ability to destroy numerically superior or mechanized forces invading North Atlantic Treaty Organization member states. ${ }^{166}$ 'Massive retaliation’ with nuclear weapons became the North Atlantic Treaty Organization battle plan in 1954 upon the realization it could not match the numerical superiority of Soviet tanks likely to be attacking if an invasion occurred. ${ }^{167}$ Nuclear proliferation also produced problems for the Soviets during the Cold War. The Soviets broke away from nuclear interdependence support to their Chinese ally when China requested Soviet assistance in developing nuclear capabilities. ${ }^{168}$ This resulted in the Chinese developing their own nuclear weapons capability in $1964 .{ }^{169}$ To place Lemnitzer's actions in context with ongoing military

${ }^{163}$ Linn, 175; Williams, 72.

${ }^{164}$ Linn, 176; Millett, et al, 479; Trauschweizer, 143-45.

165 Linn, 176; Millett, et al, 479; Trauschweizer, 143-45.

166 J. Lawton Collins, Lightning Joe: An Autobiography (Baton Rouge: Louisiana State University Press, 1979), 358-59; Trauschweizer, 21.

167 Alain C. Enthoven and K. Wayne Smith, How Much is Enough?: Shaping the Defense Program, 1961-1969 (New York: Harper and Row, Publishers, Inc., 1971), 120; Trauschweizer, 46.

${ }^{168}$ Richard Dean Burns and Joseph M. Siracusa, A Global History of the Nuclear Arms Race: Weapons, Strategy, and Politics, v. 1 (Santa Barbara, CA: ABC-CLIO, 2013), 311; Millett, et al, 476.

${ }^{169}$ Burns and Siracusa, 311; Millett, et al, 476. 
developments, the lesson learned from Exercise Sagebrush was the proposed atomic organization and battle tactics were not as lethal in real-life practice as the current conventional military capabilities and battle tactics. The Sagebrush Exercise exposed the flaw in the Pentomic structure and organization it was intended to improve upon.

General Lemnitzer became the Vice Chief of Staff of the Army in $1957 .{ }^{170}$ Lemnitzer's two years of concerted strategic actions resulted in expanded and enhanced foreign leadership peer relationships. His actions were critical to the establishment of the Japanese "National Defense Force” and the Republic of Korea forces which dramatically expanded their military capabilities. Building and enhancing these defense forces enabled the achievement of the American strategic goal of lessening its foreign defense force requirements and military budget costs in both nations.

General Lyman L. Lemnitzer- Vice Chief of Staff and Chief of Staff of the Army General Lemnitzer's contributions while Vice Chief of Staff and Chief of Staff of the Army were numerous and facilitated the accomplishment of the strategic mission. His achievements included putting the first American satellite into space, retaining Redstone Arsenal and its nuclear engineers under Army command, advancing the C-141 airplane and M-14 rifle into Army implementation, and pushing forth efforts to develop the Nike-Zeus antiballistic missile for continental air defense. Lemnitzer accomplished these feats while under pressure to reduce defense budget spending, decrease Army force structure, and increase racial integration while under national scrutiny by the civil rights movement. The American military faced a continuous period of challenge during the 1950s of maintaining conventional force readiness to immediately go to war while the American political body focused on reducing the defense budget and reliance on nuclear technology for deterrence. ${ }^{171}$ Between 1954 and 1956, 132,000 officers

170 Tucker, ed., 500 Great Military Leaders, 433; Binder, 221.

171 Trauschweizer, 230; Williams, 70-72. 
resigned. ${ }^{172}$ During his time as the Vice Chief of Staff of the Army, multiple prominent general officers retired from the Army out of a sense of hopelessness that the political administrative leadership was not supporting the advancement of military capabilities, but instead, was degrading military effectiveness and serving as a social test bed for desegregating America.

Lemnitzer and the Army received increasingly negative attention from civil rights movement leaders and politicians in the 1950s due to the employment of active duty forces in maintaining security during crisis situations. One of the best-known examples of this occurred at Little Rock, Arkansas. President Eisenhower ordered the deployment of one-thousand active duty soldiers from the $101^{\text {st }}$ Airborne Division to control the protesting crowds around Little Rock High School at the beginning of the forced integration of public schools in $1957 .{ }^{173}$ Civil rights movement leaders desired the desegregation of public schools, while politicians in areas with segregated schools desired states’ rights to keep their schools segregated. The use of federal troops as a peacekeeping force during the integration process cast a national negative perception of the Army by the nation.

Secretary of Defense Neil McElroy instructed Lemnitzer in October of 1957 to take steps to put the first American satellite into space after the Soviet Union surprised America by putting Sputnik 1 into orbit. ${ }^{174}$ Budgetary pressures on the Army lessened during this period of research and development for achieving greater national prestige. ${ }^{175}$ Major General John Medaris,

${ }^{172}$ Williamson Murray, ed., Army Transformation: A View from the U.S. Army War College (Carlisle, PA: U.S. Army War College Strategic Studies Institute, 2001), 99;

Trauschweizer, 31.

${ }^{173}$ Stephen E. Ambrose, Eisenhower: Soldier and President: The Renowned One-Volume Life (New York: Simon \& Schuster Paperbacks, 1990), 447; Binder, 230.

${ }^{174}$ L. Parker Temple III, Shades of Gray: National Security and the Evolution of Space Reconnaissance (Reston, VA: American Institute of Aeronautics and Astronautics, 2005), 116; Binder, 226.

175 Todd Tucker, Atomic America: How a Deadly Explosion and a Feared Admiral Changed the Course of Nuclear History (New York: Free Press, 2009), 92; Trauschweizer, 66. 
commander of the Army Ballistic Missile Agency, and Wernher von Braun, the scientific head of the previous Nazi Germany missile program, assessed their Redstone Arsenal program could launch a satellite in four months in response to Lemnitzer's order for an estimation of a satellite development and launch date. ${ }^{176}$ Lemnitzer’s pressure and support of the Army Ballistic Missile Agency's satellite program enabled America to reach its strategic objective of launching a satellite into space on January 31, 1958. ${ }^{177}$ When the National Aeronautics and Space Administration (NASA) was created as a separate agency from the Army in the latter part of 1958, Lemnitzer successfully argued to maintain Redstone Arsenal as an Army installation and von Braun and his team of rocket scientists under command of the Army for missile threat defense development instead of relinquishing both to the newly formed agency. ${ }^{178}$ Medaris, commander of the Army Ballistic Missile Agency, was one of four prominent general officers to resign from the Army and he did so in 1960 based on his belief that space defense should have remained an Army mission. ${ }^{179}$ Lemnitzer's staff planning actions facilitated the launching of the first American satellite into space and ensured the Army retained control over the Redstone Arsenal and its rocket scientists.

Lemnitzer’s desire for research into a long-range airborne capability to transport Army soldiers around the world resulted in the development of the C-141 airplane. His continued attendance at meetings of the House Committee on Armed Services resulted in a one billion

${ }^{176}$ Yanek Mieczkowski, Eisenhower's Sputnik Moment: The Race for Space and World Prestige (Ithaca, NY: Cornell University Press, 2013), 127; Binder, 225-26.

177 Army-Navy-Air Force Journal, “Army 'Best Fitted’ of All Services for Certain Space Missions, CoS Lemnitzer Says,” Army-Navy-Air Force Journal 97, no. 25 (February 1960) 5; Binder, 226.

${ }^{178}$ Michael J. Neufeld, Von Braun: Dreamer of Space, Engineer of War (New York: Vintage Books, 2008), 330-31; Binder, 227.

${ }^{179}$ Matthew Brzezinski, Red Moon Rising: Sputnik and the Hidden Rivalries that Ignited the Space Race (New York: Times Books, 2007), 224; Binder, 227. 
dollar allocation for the research and development producing the C-141. ${ }^{180}$ Between 1961 and 1967, the American airlift capacity rose four-hundred and seventy-five percent. ${ }^{181}$ Lemnitzer advocated the 'forward strategy' for quickly deploying tailored troop formations to specific conflicts instead of relying solely on nuclear deterrence options to prevent the expansion of communist controlled territory. ${ }^{182}$ Helicopters provided an important capability in the Vietnam War era for transporting troops and preparations for conducting air-to-ground anti-armor strikes against invading Soviet tank divisions. ${ }^{183}$ From the manager leadership philosophy perspective, increased American airlift capability enabled organizations with a mass transportation capability for effectively massing soldiers and resources at the decisive point on a battlefield. ${ }^{184}$ Similarly, the “dual capability” concept advocated by General Lemnitzer provided non-nuclear options to achieve strategic ends while continuing to advance the nation's nuclear capabilities. ${ }^{185}$ The development of the C-141 supported the forward strategy doctrine with its strategic flexibility and agility combined with long-range lift transport capability.

Lemnitzer similarly promoted the development and adoption of a more technologically advanced rifle for the Army troops and continental ballistic missile defense. First, the standard infantry Army rifle had been the M1 Garand, firing a .30-06 Springfield caliber cartridge,

${ }^{180}$ Harold H. Martin, 'Starlifter: The C-141, Lockheed’s High Speed Flying Truck,' accessed March 20, 2015, http://c141heaven.info/dotcom/truck/starlifter018.php; Binder, 244-45.

${ }^{181}$ William W. Kaufmann, The McNamara Strategy (New York: Harper \& Row Publishers, 1964), 306; Weigley, 528.

${ }^{182}$ Army Information Digest, "Annual Meeting of the Association of the US Army: Toward a Modern Army,” Army Information Digest 15 (November 1960), 25; Binder, 244.

${ }^{183}$ Daniel P. Bolger, Scenes from an Unfinished War: Low Intensity Conflict in Korea, 1966-1969, Leavenworth Papers no 19 (Fort Leavenworth: Combat Studies Institute, 1991), 95; Trauschweizer, 178-79.

${ }^{184}$ Bolger, 96; Linn, 8-9.

${ }^{185}$ Robert T. Davis II, The Challenge of Adaptation: The US Army in the Aftermath of Conflict, 1953-2000, The Long War Series Occasional Paper 27 (Fort Leavenworth, KS: Combat Studies Institute Press, 2008), 29; Lyman L. Lemnitzer, "Why We Need a Modern Army,” Army 10, no. 2 (September 1959): 16-22. 
carrying eight rounds of ammunition in its internal magazine, and weighing approximately ten pounds. ${ }^{186}$ The M-14 fired a less expensive cartridge in .308 Winchester caliber (7.62x 51mm NATO) with similar ballistics and lethality as the .30-06 Springfield caliber. The M-14 also accepted a detachable box magazine of twenty round capacity and weighed approximately one pound less than the M1 Garand. Transforming the Army common rifle from the M1 Garand to the M-14 significantly reduced the budget requirements for ammunition while increasing the fighting capability of the ground soldiers with lighter rifles and additional ammunition capacity. Secondly, Lemnitzer was a catalyst to the development of the Nike-Zeus anti-ballistic missile in order to defend against the characteristic threat of attacks by Soviet Union intercontinental ballistic missiles. ${ }^{187}$ His origins in the Coastal Artillery Corps may have been stoked with the revival of the necessity for a homeland defense from an enemy threat, albeit of another type than was present in the 1920s. Lemnitzer's accomplishment of magnifying the combat lethality for the Army soldier contributed to the achievement of the national strategic goal of decreasing the defense budget.

Lemnitzer was successful with his rationale in opposing the implementation in 1959 of Admiral Radford's drastic Army personnel cut recommendation from 1957 and in preventing the National Security Council from reducing the number of deployed Army forces is support of the defense of the Republic of Korean by twenty-five percent. ${ }^{188}$ Lemnitzer successfully illuminated and justified the necessity of ground forces to prevent North Korean infiltrations into South Korean territory. ${ }^{189}$ Nuclear strikes against invading North Korean forces would destroy much of

${ }^{186}$ Leroy Thompson, The M1 Garand (Westminster, MD: Osprey, 2012), 6; Trauschweizer, 245.

${ }^{187}$ Benson D. Adams, Ballistic Missile Defense (New York: American Elsevier Publishing Company, 1971), 47; Binder, 246.

188 Trauschweizer, 65; Binder, 234.

189 Trauschweizer, 65; Binder, 234. 
South Korea's infrastructure instead of protecting critical infrastructure. Ground forces were much more capable of protecting critical infrastructure.

The Cold War threats by Soviet Union Premier Nikita Khrushchev of launching intercontinental ballistic missile (ICBM) at the United States and restricting American convoys from freedom of maneuver access through East Germany controlled areas to West Berlin justified the need for heightened American military capabilities. ${ }^{190}$ Khrushchev’s bizarre threats to attack the United States for its actions to protect free trade around the world repeatedly shocked Averell Harriman, the American ambassador to the Soviet Union and earlier ambassador to Paris as Chief of the Marshall Plan with Colonel Bonesteel. ${ }^{191}$ John Foster Dulles, the Secretary of State, evolved from a massive nuclear retaliation mindset as the first line of Cold War national defense to a believer in the use of conventional forces in limited engagement conflicts. ${ }^{192}$ This was partly due to the Soviet Union's advancements in nuclear weapon capability increasing the likelihood of mutually assured destruction (MAD) by both parties using nuclear weapons. The failure of the communist ideology in the Korean War and awareness of the nuclear capabilities threatening his country influenced Khrushchev to provide additional support to insurgent groups as they attempted to spread communism in Southeast Asia rather than employ conventional or nuclear forces. ${ }^{193}$ Lemnitzer strove to improve and maintain the military capabilities of the Army in response to Cold War threats, while President Eisenhower's policies repeatedly reduced the

${ }^{190}$ Gunter Bischof, Stefan Karner, Barbara Stelzl-Marx, eds., The Vienna Summit and its Importance in International History (Lanham, MD: Lexington Books, 2014), 13-14; Binder, 239, 233.

${ }^{191}$ Behrman, 193; Harriman, “Oral History Interview with W. Averell Harriman,” 5-6; Bonesteel, “General Charles H. Bonesteel III, US Army Retired,” Appendix, 1; Binder, 239.

192 Nina Tannenwald, The Nuclear Taboo: The Unites States and the Non-Use of Nuclear Weapons Since 1945 (New York: Cambridge University Press, 2007), 188-89; Binder, 239.

${ }^{193}$ Weigley, 542; Trauschweizer, 69. 
annual defense budget to achieve and maintain a national and strategic objective, and a balanced national budget.

During this time in the late 1950s, four prominent general officers retired due to their belief that President Eisenhower’s ‘New Look’ policies were overly degrading Army capabilities. The first to retire was General Matthew Ridgway in June 1955, the current Chief of Staff of the Army and former commander of the $82^{\text {nd }}$ Airborne Division during World War II, due to his belief that conventional American forces should be utilized to defeat Soviet forces, not nuclear strikes. ${ }^{194}$ The second to retire was Lieutenant General James Gavin, who had gained fame as the commanding general of the $82^{\text {nd }}$ Airborne Division during World War II and then served as the chief of Army research and development. ${ }^{195}$ Gavin’s reason for retiring in March of 1958 was due to his belief that space exploration should remain an Army mission and he desired to campaign as a civilian against the Eisenhower administration’s 'New Look’ policies that negatively affected the Army. ${ }^{196}$ The third to retire was General Maxwell Taylor, who also gained national prominence for his actions during World War II, and was the Chief of Staff of the Army while Lemnitzer was Vice Chief of Staff. ${ }^{197}$ Taylor retired in July 1959 due to his similar

194 Jonathan M. Soffer, General Matthew B. Ridgway: From Progressivism to Reaganism, 1895-1993 (Westport, CT: Praeger Publishers, 1998), 183, 189; Trauschweizer, 36; Weigley, 526.

195 Weigley, 526; Binder, 235.

${ }^{196}$ Andrew Heiskell, “General Gavin Tells What U.S. Needs to Meet Crisis of Limited War,” Life 45, no. 4 (July 28, 1958): 89; Binder, 235.

${ }^{197}$ Weigley, 526; Maxwell D. Taylor, Swords and Plowshares (New York: W.W. Norton and Company, 1972), 174. 
dissatisfactions with 'New Look’ policies that negatively affected the Army. ${ }^{198}$ General Lemnitzer became the Chief of Staff of the Army following Taylor's retirement. ${ }^{199}$ The fourth general officer to retire was Major General John Medaris in 1960 based upon his belief that space defense should have remained an Army mission. ${ }^{200}$

An essential Lemnitzer contribution as Chief of Staff of the Army was the flexible response concept. The flexible response concept involved positioning military personnel and stockpiles overseas and stateside with the capability to rapidly deploy them to an initial crisis before a full conflict arose to involve nuclear weapons. ${ }^{201}$ The purpose of the Army's flexible response concept was to provide another response option as a course of action for Cold War

198 Taylor, 174-75; Binder, 235; Weigley, 526. Interestingly, the monograph author found Ingo Trauschweizer's book, The Cold War U.S. Army: Building Deterrence for Limited War, illustrated a pro-Maxwell Taylor perspective on the issue of resignation from the Eisenhower administration in July 1959 and later re-hiring by the Kennedy administration in June 1961 [Trauschweizer, 65; Binder, 235]. L. James Binder's book, Lemnitzer: A Soldier for His Time, mentions that Taylor resigned from frustration with President Eisenhower's 'New Look' policies. Similarly, Binder's book states that Taylor was re-hired by President Kennedy into a new position that Kennedy created titled 'Military Representative of the President' and overseeing General Lemnitzer, who had been the Vice Chief of Staff of the Army to Taylor before he resigned [Taylor, 197-98; Binder, 285; Trauschweizer, 122; David Talbot, Brothers: The Hidden History of the Kennedy Years (New York: Free Press, 2007), 68; Lawrence Freedman, Kennedy's Wars: Berlin, Cuba, Laos, and Vietnam (New York: Oxford University Press, 2000), 40; H.R. McMaster, Dereliction of Duty: Lyndon Johnson, Robert McNamara, the Joint Chiefs of Staff, and the Lies that Led to Vietnam (New York: HarperCollins Publishers, 1997), 15]. This piece of history is barely mentioned in Trauschweizer's book [Trauschweizer, 122; Binder, 285]. Placed into context, the position Kennedy created placed Taylor as a military advisor to the Presidency directly in between General Lemnitzer's position as Chairman of the Joint Chiefs of Staff and President Kennedy [Chapter 1 from H.R. McMaster's Dereliction of Duty (New York: Harper Collins Publishers, 1997) covers in more detail the weak relationship between Kennedy/McNamara and the Joint Chiefs of Staff]. Lemnitzer continued to advocate for the benefit of the Army in a command climate that was anti-military growth while obeying the orders of the President and those appointed over him.

${ }^{199}$ United States Congress, Nomination of Gen. Lyman L. Lemnitzer to be Chief of Staff of the Army: Hearing Before the Committee on Armed Services, United States Senate, Eightysixth Congress, First Session, on the Nomination of Gen. Lyman L. Lemnitzer, U.S. Army, to be Appointed as Chief of Staff of the Army for 2 Years, Vice Gen. Maxwell D. Taylor (Washington, DC: US Government Printing Office, April 23, 1959), 1.

${ }^{200}$ Brzezinski, 224; Binder, 227.

${ }^{201}$ Binder, 243; Millett, et al, 501; Trauschweizer, 2. 
aggressions other than nuclear retaliation. Lemnitzer was a vocal proponent of the flexible response concept. ${ }^{202}$ Within the context of international strategic leadership, there was an underlying acknowledgement between the greater possibility of mutually assured nuclear destruction (MAD) from nuclear proliferation and the want of increasing the frequency of limited war conflicts. ${ }^{203}$ A regional hegemon's national infrastructure would not be destroyed while they conducted limited wars in remote territories no matter if they won or lost. Two studies were published in book format in 1957 — Limited War by Robert Osgood and Nuclear Weapons and Foreign Policy by Henry Kissinger — that reached the overall conclusion that national reliance on nuclear arms for national defense diminished a nation's ability to participate in international conflicts at levels lower than total war or prevent limited conflicts from escalating to total war levels. ${ }^{204}$ North Atlantic Treaty Organization studies in 1964 estimated the civilian casualty rates to surpass 100 million from a total war involving nuclear strikes and counterstrikes in Central Europe. ${ }^{205}$ European leaders became more receptive to flexible response as a policy and more guarded to massive retaliation warfare when viewed in this context. Many Army general officers (including James Gavin, Matthew Ridgway, and Maxwell Taylor) and John F. Kennedy believed Eisenhower administration's dependence on nuclear deterrence had left the American military and Army unprepared for responding to situations smaller in size or scope than requiring nuclear strike capability. ${ }^{206}$

${ }^{202}$ Freedman, 110; Binder, 322.

${ }^{203}$ C.F. von Weizsacker, "European Armaments in the 1980s," Bulletin of the Atomic Scientists 36, no. 10 (December 1980): 8; Trauschweizer, 69.

204 Trauschweizer, 173; Robert E. Osgood, Limited War: The Challenge to American Strategy (Chicago: University of Chicago Press, 1957); Henry Kissinger, Nuclear Weapons and Foreign Policy (New York: Harper \& Brothers Publishing, 1957), 56, 145-49.

205 Trauschweizer, 145.

206 Trauschweizer, 173; Weigley, 526; Dupuy and Dupuy, 1270; Taylor, 174-75. 
President Kennedy increased the size of the military personnel by one-quarter million men at the time the flexible response concept was gaining credibility. ${ }^{207}$ He was also a large supporter of Special Operations Forces in the undeclared wars against communism ideology. Kennedy increased the Special Forces branch of the Army by one-hundred and fifty percent and approved the 'Green Beret' as the official headgear during his short time in office. ${ }^{208}$ Kennedy believed the Army's dual airlift and reserve force capacities would enable America to fight limited wars in Europe similar to the Korean War. ${ }^{209}$

Presidents Kennedy and Johnson’s emphasis on flexible response for a defense policy instead of massive nuclear retaliation from Europe to Southeast Asia enabled a balance of power to be preserved during periods of high Cold War tensions. ${ }^{210}$ Secretary of Defense Robert McNamara established that American defense policy was not merely nuclear deterrence, but also included flexible response with the newly developed C-141 airlift capacity to transport Army forces to crisis points around the world. ${ }^{211}$ McNamara believed a reliance on nuclear weapons technology for massive retaliation by the Eisenhower administration had handicapped the conventional force's ability to respond to limited wars. ${ }^{212}$ As such, Operation Big Lift

${ }^{207}$ Millett, et al, 501.

${ }^{208}$ Geoffrey Williams, The Permanent Alliance: The European-American Partnership, 1945-1984 (Leyden, Netherlands: A.W. Sijthoff, 1977), 86; Weigley, 543.

209 Ted Galen Carpenter, ed., NATO at 40: Confronting a Changing World (Lexington, VA: Cato Institute, 1990), 5; Weigley, 542.

${ }^{210}$ D. Robert Worley, Aligning Ends, Ways, and Means: An Examination of the U.S. National Security Strategy (Raleigh, NC: Lulu.com, 2006), 113; Trauschweizer, 114.

${ }^{211}$ Robin Higham and Mark Parillo, eds., The Influence of Airpower upon History: Statesmanship, Diplomacy, and Foreign Policy Since 1903 (Lexington: University Press of Kentucky, 2013), 195: Weigley, 527.

${ }^{212}$ Weigley, 527; Blight and Lang, 79-80. 
demonstrated to America’s Cold War allies and enemies in 1963 the American strategic and operational capability to airlift a division from one continent to another. ${ }^{213}$

Major General Bonesteel became the secretary to the Chief of Staff of the Army, General Lemnitzer, on March 1958 through September 1960. ${ }^{214}$ He observed Lemnitzer advocating for an increase in conventional force capability. ${ }^{215}$ Lemnitzer began advocating as early as May 1960 for developing and expanding the capabilities of the conventional force as a method for responding to limited conflict scenarios instead of responding with nuclear strike capabilities. ${ }^{216}$ Lemnitzer promoted conventional force capability for utilization as an other-than-nuclear-weapons response option in cases of limited warfare. ${ }^{217}$ Conventional force capability to meet enemy threats with superior combat power while avoiding mutually assured destruction possibilities through employment of nuclear retaliatory strikes would be a viable and preferred response option. ${ }^{218}$ Bonesteel's next assignment was the Special Assistant to the Chairman of the Joint Chiefs of

${ }^{213}$ Poole, 211; Weigley, 528.

${ }^{214}$ Lawrence S. Kaplan and Kathleen A. Kellner, "Lemnitzer: Surviving the French Military Withdrawal,” in Generals in International Politics, ed. Robert S. Jordan, (Lexington: The University Press of Kentucky, 1987), 97; Bonesteel, "General Charles H. Bonesteel III, US Army Retired,” Appendix A, 5.

${ }^{215}$ Kaplan and Kellner, 97.

${ }^{216}$ Ibid.

${ }^{217}$ Ibid.

${ }^{218}$ Ibid. 
Staff from October 1960 to May $1961 .{ }^{219}$ In this assignment, Bonesteel served directly under General Lemnitzer, then Chairman. ${ }^{220}$

Lemnitzer’s institutional coordination of the Single Integrated Operational Plan (SIOP) while Chief of Staff of the Army was a critical contribution for achieving strategic objectives with the military services. The Single Integrated Operational Plan was developed between 19591960, with a significant coordinating achievement occurring during a joint meeting General Lemnitzer called between the service chiefs. ${ }^{221}$ Lemnitzer's purpose for the meeting was define each services' offensive and defensive roles in strategic nuclear operations. ${ }^{222}$ Lemnitzer's insistence on the service chiefs meeting resulted in the Department of Defense establishing a unified plan for nuclear operations during the Cold War. ${ }^{223}$ Lemnitzer's critical contributions while serving as the Chief of Staff of the Army produced the flexible response concept and Single Integrated Operational Plan. These two achievements provided tactical policy options for the services to follow in case of a breakout of nuclear, non-nuclear, limited, or general war to accomplish the strategic objective of defending the nation.

Lemnitzer's abundant contributions while serving as Vice Chief of Staff and Chief of Staff of the Army contributed to the accomplishment of strategic missions. Placing the first

${ }^{219}$ United States Congress, Nominations: General L. L. Lemnitzer, Chairman, JCS, and General G. H. Decker, Army Chief of Staff: Hearings Before the United States Senate Committee on Armed Services, Eighty-Sixth Congress, Second Session (Washington, DC: US Government Printing Office, August 20, 1960), 1; Bonesteel, "General Charles H. Bonesteel III, US Army Retired,” Appendix A, 5; Binder, 247.

${ }^{220}$ United States Congress, Nominations: General L. L. Lemnitzer, Chairman, JCS, and General G. H. Decker, Army Chief of Staff: Hearings Before the United States Senate Committee on Armed Services, Eighty-Sixth Congress, Second Session (Washington, DC: US Government Printing Office, August 20, 1960), 1; Bonesteel, “General Charles H. Bonesteel III, US Army Retired,” Appendix A, 5; Binder, 247.

${ }^{221}$ Binder, 246; Lori Lyn Bogle, ed., The Cold War: National Security Policy Planning from Truman to Reagan and from Stalin to Gorbachev (New York: Routledge, 2001), 45-48.

222 Binder, 246; Bogle, 45-48.

${ }^{223}$ Binder, 246. 
American satellite into space redeemed national pride from the Soviet Union’s first-to-launch boast. Retaining Redstone Arsenal and its nuclear engineers under Army command enabled the continued advancement of missile defense developments. Advancing the acquisition of the C-141 airplane and integrating the M-14 rifle into Army inventories improved the capabilities, responsiveness, and the lethality of the American soldier. Developing the Nike-Zeus antiballistic missile improved continental air defense during the Cold War. Remarkably, Lemnitzer's leadership ability and personality enabled him to simultaneously accomplish these feats while under significant political pressure to reduce defense budget spending, sustain Army force size reduction and endure intense national scrutiny by the civil rights movement. He provided strategic leadership while many other prominent general officers were resigning from the Army out of a sense that their political leadership was not supporting the advancement of military capabilities.

General Lemnitzer was Chairman of the Joint Chiefs of Staff during the course of the Bay of Pigs operation. The role of the Chairman of the Joint Chiefs of Staff is to provide best military advice and oversee the individual service chiefs for recommendations to the President and National Security Council on military related issues. The beginning of Lemnitzer’s Chairmanship saw the election of President John F. Kennedy to office and Robert McNamara as the Secretary of Defense. Lemnitzer's special assistant at the time the Bay of Pigs Operation occurred was Major General Bonesteel. 224

The Bay of Pigs’ operational purpose in April 1961 was to overthrow the Fidel Castro regime in Cuba under the guise of a domestic insurgency similar to the Guatemalan insurgency

${ }^{224}$ Jack Schulimson, The Joint Chiefs of Staff and the War in Vietnam, 1960-68, Part 1, (Washington, DC: Office of Joint History, 2011), 92, accessed March 20, 2015, http://www.dtic.mil/doctrine/doctrine/ history/jcsvietnam_pt1.pdf; Binder, 258. 
that usurped a communist regime in $1954 .{ }^{225}$ The Central Intelligence Agency was the originator and primary planner of the Bay of Pigs Operation, albeit requiring military support in the final stages of development. ${ }^{226}$ The Central Intelligence Agency’s team of planners did not write down their plans and planned only their individual portions of the operation in a decentralized manner in order to maintain secrecy. ${ }^{227}$ This method of planning did not produce an overall plan that was synchronized, feasible, or complete. ${ }^{228}$ Lemnitzer and the Joint Chiefs of Staff's assessments of the Central Intelligence Agency’s plan — and their subject matter experts' assessments of the plan - arrived at ratings of weak and unlikely of success. ${ }^{229}$ However, Lemnitzer and the Joint Chiefs of Staff were not able to offer their consultation to the final Bay of Pigs Operation plan because the Central Intelligence Agency continued to modify the plan as the D-Day approached. ${ }^{230}$ As a result, Lemnitzer's repeated negative assessments of the Bay of Pigs Operation plan did not prevent the execution from occurring and yielded a strategic failure and embarrassment. Disappointed with the Joint Chiefs of Staff advisors, President Kennedy summoned retired General Maxwell Taylor to investigate the Bay of Pigs Operation. ${ }^{231}$ Interestingly, the Central Intelligence Agency — the originator and primary planner of the Bay of

${ }^{225}$ James Blight and Janet Lang, The Fog of War: Lessons from the Life of Robert S. McNamara (New York: Rowman and Littlefield, 2005), 39; Binder, 255.

${ }^{226}$ Blight and Lang, 147; Taylor, 181; Binder, 259-60; Lawrence S. Kaplan, Ronald Dean Landa, Edward J. Drea, History of the Office of the Secretary of Defense, v. 5: The McNamara Ascendancy, 1961-1965 (Washington, DC: Office of the Secretary, Historical Office, 2006), 189.

${ }^{227}$ Taylor, 182; Freedman, 138; Binder, 263.

${ }^{228}$ Kaplan, et al, 175-76; Freedman, 127, 130; Binder, 263.

${ }^{229}$ Kaplan, et al, 189; Binder, 259, 261.

230 Taylor, 187; Binder, 264.

${ }^{231}$ Freedman, 40; Taylor, 181; Talbot, 50-52; Binder, 270. 
Pigs Operation — was represented on the investigation panel by their Director, Allen Dulles. ${ }^{232}$ To further complicate matters, upon completion of the investigation President Kennedy asked Maxwell Taylor to return from retirement to active duty status in a newly created position of Military Representative between the presidency and the Chairman of the Joint Chiefs of Staff. ${ }^{233}$ President Kennedy’s action distanced General Lemnitzer further away from the presidency in the new chain of command and in a subordinate position to his previous boss who himself had retired from active duty due to his dislike of Eisenhower's New Look policies.

Lemnitzer facilitated growth of the US Army force structure under President Kennedy following the Bay of Pigs Operation and the post operation investigation. In May of 1961, the Army transitioned to the Reorganization Objective Army Division (ROAD) method for Army force structure to provide increased firepower, maneuverability, and flexibility, which the current force structure lacked. ${ }^{234}$ Three brigade headquarters now composed each division, instead of the five battle groups the pentomic division was based upon. ${ }^{235}$ Lemnitzer's Chief of Staff of the Army predecessor, General Taylor, had approved the pentomic division adoption in 1956 to prevent the decline in Army funding requirements by providing a need for self-sufficient conventional force strength in each battle group. ${ }^{236}$

Lemnitzer wrote an interesting memorandum to President Kennedy prior to his May 1961 meeting with Soviet Union Premier Khrushchev to discuss global issues between the prominent

${ }^{232}$ John Prados, Safe for Democracy: The Secret Wars of the CIA (Lanham, MD: Rowman and Littlefield, 2006), 265; Reardon, 214-15. The pentomic concept was similar to the 21st century brigade combat team concept of incorporating brigade sustainment battalions into the force structure.

233 Taylor, 197; Binder, 285.

${ }^{234}$ Poole, 542; Trauschweizer, 114.

${ }^{235}$ Weigley, 537; Trauschweizer, 115, 52.

${ }^{236}$ Trauschweizer, 52, 231. 
world powers. ${ }^{237}$ The memorandum communicated to the president that America was the preeminent military power of the world and would support Kennedy in any manner he deemed fit to deploy its capabilities. ${ }^{238}$ Lemnitzer’s memorandum provided Kennedy with a confirmation that his country's military capacity was greater than any other in the world while he discussed national strategic objectives with Khrushchev.

Lemnitzer departed the Chairman of the Joint Chiefs of Staff position shortly before the Cuban Missile Crisis, in October 1962. General Maxwell Taylor became Chairman of the Joint Chiefs of Staff in October 1962. ${ }^{239}$ The Cuban Missile Crisis occurred when the Soviet Union began building missile sites in Cuba to protest the North Atlantic Treaty Organization missile sites in Turkey and Italy. ${ }^{240}$ Lemnitzer's advice to President Kennedy and Vice-President Lyndon B. Johnson was that America could not remove North Atlantic Treaty Organization missiles from Europe without the approval of its allies because they were not American materials to move. ${ }^{241}$ The Soviet Union ultimately agreed to withdraw their missile capabilities from Cuba on the understanding the United States would discontinue its naval blockade and not invade Cuba. ${ }^{242}$ Lemnitzer tactfully promoted a healthy respect for the North Atlantic Treaty Organization's procedures at this instance and in many others to further legitimize and strengthen the strategic alliance he was instrumental in forming.

General Lemnitzer’s diplomatic actions contributed to two limited military conflicts from evolving into general military conflicts. In the presidential change of command briefs of January

${ }^{237}$ Binder, 291.

238 Trauschweizer, 127; Binder, 292.

239 Taylor, 252; Freedman, 110.

${ }^{240}$ Millett, et al, 504-05; Binder, 309.

${ }^{241}$ Nasuh Uslu, The Turkish-American Relationship Between 1947 and 2003: The History of a Distinctive Alliance (Hauppauge, NY: Nova Science, 2003), 145; Freedman, 211; Binder, 310.

${ }^{242}$ Millett, et al, 506; Binder, 309. 
1961, retiring President Eisenhower instructed the incoming President Kennedy there was high probability the United States would need to become involved in the Laos civil war to prevent the spread of communism. ${ }^{243}$ Lemnitzer prevented the first conflict during his visit to Thailand in May of 1961 while serving as Chairman of the Joint Chiefs of Staff and successfully set the conditions preventing a Thailand-Laos War from occurring. ${ }^{244}$ Lemnitzer accomplished this by deploying two American garrisons to assist Thailand in re-organizing and generating plans to defeat the Laos incursions into its territory. ${ }^{245}$ The plan also convinced the leaders of Thailand, the Soviet Union, and China that Laos was not significant enough to go to war over. ${ }^{246}$

Lemnitzer became the commander in chief of the US European Command (USCINCEUR) in November 1962 and the Supreme Allied Commander Europe (SACEUR) in January 1963. ${ }^{247}$ The Supreme Allied Commander Europe position commanded the military forces of the North Atlantic Treaty Organization. ${ }^{248}$ He prevented the second conflict from beginning in 1964. Lemnitzer's diplomatic conversations with the leaders of Turkey and Greece influenced Turkey from not seizing the island of Cyprus whose population was composed of Turkish and Greek descent. ${ }^{249}$ Lemnitzer likely prevented the Laos and Thailand Wars — but not the later Vietnam War — due to intelligence indicating the potential for future conflict at these two locations. Intelligence was not pointing towards Vietnam as a candidate for significant

${ }^{243}$ Yuen Foong Khong, Analogies at War: Korea, Munich, Dien Bien Phu, and the Vietnam Decisions of 1965 (Princeton, NJ: Princeton University Press, 1992), 81; Millett, et al, 507.

${ }^{244}$ Poole, 131; Binder, 290.

${ }^{245}$ Poole, 135-36; Binder, 290.

246 Poole, 135-36; Binder, 290.

${ }^{247}$ Poole, 203; Binder, 311.

${ }^{248}$ Millett, et al, 466; Binder, 313.

${ }^{249}$ Panagiotis Dimitrakis, Military Intelligence in Cyprus: From the Great War to Middle Ease Crises (New York: Palgrave Macmillan, 2010), 121; Binder, 327-28. 
violent conflict. Lemnitzer's operational actions in Thailand and Cyprus prevented general wars from beginning and supported the accomplishment of the nation's strategic objective for peace in the European theater.

General Bonesteel's emphasis on realistic training was illustrated when he was the $24^{\text {th }}$ Infantry Division Commander in Germany from May 1961 to March 1962. ${ }^{250}$ Bonesteel ordered the VII Corps G-2 Intelligence Officer to provide Soviet minefield doctrine for his men to train against. ${ }^{251}$ Bonesteel wanted training which would accurately replicate the most likely enemy force and the enemy tactics they would be facing. ${ }^{252}$ He also issued policies to govern garrison conduct in a similar manner to conduct directed while in combat in order to maximize the strengths of the US force and minimize the strength of the Soviet Union. Examples included false field fortifications and helicopter landing zones to confuse the enemy's estimation of the foreword edge of the battle area if they chose to invade West Germany. ${ }^{253}$

Bonesteel's principle of realistic training supports his principle of non-reliance on technology. Radio checks, Long Range Reconnaissance Patrols, and reaction to enemy contact drills were examples actions he highlighted as the $24^{\text {th }}$ Infantry Division Commander. ${ }^{254}$ Bonesteel did this to prevent reliance on technology for radio synchronization, early alert sentry systems, and antiaircraft artillery systems. ${ }^{255}$ He was more reliant and trusting of the people under

250 James F. Gebhardt, Eyes Behind the Lines: US Army Long Range Reconnaissance and Surveillance Units, Global War on Terrorism Occasional Paper 10 revised edition (Fort Leavenworth, KS: Combat Studies Institute Press, 2005), 22, 23, 29; Amos Jordan, 333; Bonesteel, “General Charles H. Bonesteel III, US Army Retired,” Appendix A, 4; Bolger, 46.

${ }^{251}$ Bonesteel, “General Charles H. Bonesteel III, US Army Retired,” 170-71.

252 Bolger, 46; Gebhardt, 20; Bonesteel, “General Charles H. Bonesteel III, US Army Retired," 170-71.

253 Bonesteel, “General Charles H. Bonesteel III, US Army Retired,” 167-69.

${ }^{254}$ Gebhardt, 23-24; Bonesteel, “General Charles H. Bonesteel III, US Army Retired,” 298-301; Ibid, Appendix A, 5.

301.

${ }^{255}$ Bolger, 11; Bonesteel, “General Charles H. Bonesteel III, US Army Retired,” 298- 
his command than the technology designed to accomplish human tasks. Bonesteel, however, continuously worked with the research and development departments to design equipment that was beneficial for critical capabilities required by military users. The Bailey Bridge, infrared night vision, and targeting devices for use on the West German border are additional examples. ${ }^{256}$

General Bonesteel revitalized the empowerment of the Republic of Korea (ROK) military when he became the Commanding General of Eighth US Army, Commander in Chief United Nations Command (CICUNC), and US Forces Korea (USFK) from September 1966 to October 1969. ${ }^{257}$ The 1960s were a time of turmoil in South Korea. Syngman Rhee, South Korea’s first president, was overthrow from office by student demonstrators led by Major General Park Chung Hee, who later experienced an assassination attempt in $1968 .{ }^{258}$ Bonesteel empowered the Republic of Korea military by shifting responsibility for internal security and policing to the ROK from the USFK similar to General Lemnitzer's actions in the previous decade. Bonesteel and the ROK leadership shifted responsibility for internal security by initiating a militia method, which resulted in two million men and sixty-thousand units as the militia force. ${ }^{259}$ USFK requirements for policing were lessened because of employing the ROK militia for internal security and enabled USFK because they could prioritize the disruption of the North Korean People’s Army invasion forces. ${ }^{260}$ Interestingly, Bonesteel recommended the $38^{\text {th }}$ Parallel as the separation

${ }^{256}$ Bonesteel, “General Charles H. Bonesteel III, US Army Retired,” 303-04.

${ }^{257}$ Bolger, 127, 8; Bonesteel, “General Charles H. Bonesteel III, US Army Retired,” 22223; Ibid., Appendix A, 5.

${ }^{258}$ Don Oberdorfer, The Two Koreas: A Contemporary History (New York: Basic Books, 1997), 10-11.

${ }^{259}$ Charles H. Bonesteel, III, “The Meaning of National Military Power Today and Tomorrow," in Issues of National Security in the 1970s, ed. Amos A. Jordan, Jr. (New York: Frederick A. Praeger Publishers, 1967), 60-74.

${ }^{260}$ Bonesteel, “The Meaning of National Military Power Today and Tomorrow,” 60-74. 
boundary between South and North Korea while working with Dean Rusk during the Allied negotiation for distributing post-World War II zones of control. ${ }^{261}$

Lemnitzer's responsibilities as the Supreme Allied Commander Europe (SACEUR) from 1963-1969 were to deter the Soviets from attacking into the North Atlantic Treaty Organization states and defend in the case of a Soviet attack. ${ }^{262}$ The American priority for military manning and equipping was the Vietnam War, not Europe. As a result, the number of Army forces in Europe dropped from 272,000 in 1961 to 170,000 by $1970 .{ }^{263}$ The Soviets had made significant advances in ground, air, and nuclear weapons during the time period America was concentrating its efforts in the Vietnam War. ${ }^{264}$ To accomplish the mission of deterring a Soviet attack, Lemnitzer fought to maintain the same number of combat units to maneuver in defense of Europe — albeit not fully staffed — while sending individual soldiers to augment the Army formations fighting in Vietnam. ${ }^{265}$ Lemnitzer's underlying belief was that numerous combat and supply units could safeguard larger American defense budget allocations for the European theater while partially undermanned, versus a lesser number of fully manned units could from American or European defense budgets. ${ }^{266}$ Lemnitzer, along with the following Supreme Allied Commander

261 Tessa Morris-Suzuki, Exodus to North Korea: Shadows from Japan's Cold War, (Lanham, MD: Rowman and Littlefield, 2007), 46; Schnabel, 9-10; Oberdorfer, 6; Spector, 139; Donovan, 103; Dean Rusk, written quote, Harry S. Truman Library and Museum website. Accessed March 24, 2015, http://www.trumanlibrary.org/whistlestop/study_collections/korea/ large/world.htm.bak.

${ }^{262}$ Robert S. Jordan, ed., Generals in International Politics (Lexington: The University Press of Kentucky, 1987), xiv; Poole, 203.

263 Trauschweizer, 180.

${ }^{264}$ Charles R. Schrader, History of Operations Research in the United States Army, 3, 1973-1995 (Washington, DC: Center of Military History, 2009), 9; Millett, et al, 566-67.

${ }^{265}$ Lawrence S. Kaplan, “McNamara, Vietnam, and the Defense of Europe,” in War Plans and Alliances in the Cold War: Threat Perceptions in the East and West, eds. Vojtech Mastny, Sven G. Holtsmark, and Andreas Wenger (New York: Routledge, 2006), 294-95; Trauschweizer, 180.

${ }^{266}$ Kaplan, “McNamara, Vietnam, and the Defense of Europe,” 295; Trauschweizer, 183. 
Europe (SACEUR) General Andrew Goodpaster (1969-74), applied the flexible response concept of responding to Soviet threats or attacks with appropriate responses. ${ }^{267}$ Flexible response became the official North Atlantic Treaty Organization military policy in 1967. ${ }^{268}$ The alliance’s strategic concept involved making the costs of an invasion appear greater to the Soviets than the potential gains.

Lemnitzer's actions as the dual-hatted Commander in Chief of the US European Command (USCINCEUR) and Supreme Allied Commander Europe (SACEUR) facilitated the strengthening of alliances between North Atlantic Treaty Organization member states. During this time the French withdrew from the integrated North Atlantic Treaty Organization command and forced the Supreme Headquarters Allied Powers Europe (SHAPE) to relocate from France to a location outside of France. ${ }^{269}$ Lemnitzer's managerial leadership skill — coupled with the North Atlantic Treaty Organization member states’ teamwork — ultimately strengthened this alliance. He accomplished numerous feats during this time, but two note-worthy accomplishments stand out for specific recognition. Lemnitzer's diplomatic feats made possible the critical standardization of the 7.62 millimeters cartridge for the North Atlantic Treaty Organization and the relocation of the Supreme Headquarters Allied Powers Europe (SHAPE) from France to Belgium. ${ }^{270}$

Standardization of common use equipment within the North Atlantic Treaty Organization's military forces was important for increasing interoperability among the different member states' forces supporting unified missions. ${ }^{271}$ Lemnitzer, as the Supreme Allied

${ }^{267}$ Ryan C. Hendrickson, Diplomacy and War at NATO: The Secretary General and Military Action after the Cold War (Columbia: University of Missouri Press, 2006), 29; Trauschweizer, 136.

${ }^{268}$ Millett, et al, 502; Trauschweizer, 145.

${ }^{269}$ Binder, 325.

${ }^{270}$ Nixon, 507; Binder, 325.

${ }^{271}$ Reardon, 343; Binder, 324. 
Commander Europe, convinced the alliance to adopt the 7.62 millimeters cartridge for standardization just before America decided to switch from the M-14 firing 7.62 x 51 millimeters cartridges to the M-16 firing 5.54 x 45 millimeters cartridges. ${ }^{272}$

The second strategic feat occurred when French President Charles de Gaulle, Lemnitzer’s World War II acquaintance, instructed Lemnitzer as the Supreme Allied Commander Europe, in March 1966 to move his Supreme Headquarters Allied Powers Europe headquarters out of France within one year. ${ }^{273}$ De Gaulle declared France’s withdrawal from the North Atlantic Treaty Organization membership. ${ }^{274}$ Upon his election to the French presidency in 1958, de Gaulle had campaigned for a tripartite directorate atop North Atlantic Treaty Organization made up of France, Great Britain, and America. ${ }^{275}$ When the North Atlantic Treaty Organization denied de Gaulle’s request, he initiated other steps to expand France’s power over Western Europe and usurp the power of the North Atlantic Treaty Organization. ${ }^{276}$

Charles de Gaulle’s expulsion of Supreme Headquarters Allied Powers Europe (SHAPE) headquarters out of France was the most significant transfer of military resources during a nonwartime period in known history. ${ }^{277}$ Lemnitzer was able to accomplish this enormous feat within the timeframe allotted. ${ }^{278} \mathrm{He}$ did so by balancing the strategic partnerships within the North Atlantic Treaty Organization and leveraging the placement of headquarters locations to enhance

${ }^{272}$ Ken Perkins, Weapons and Warfare: Conventional Weapons and their Roles in Battle (London: Brassey’s Defense Publishers, 1987), 197; Binder, 325.

${ }^{273}$ Frederic Bozo, De Gaulle, the United States, and the Atlantic Alliance: Two Strategies for Europe, trans. Susan Emanuel (Lanham, MD: Rowman and Littlefield, 2001), 169;

Trauschweizer,184; Millett, et al, 502; Binder, 331; Kaplan and Kellner, 106.

274 Trauschweizer, 184; Millett, et al, 502; Binder, 331; Kaplan and Kellner, 106.

${ }^{275}$ Kaplan and Kellner, 103; Richard F. Kuisel, Seducing the French: The Dilemma of Americanization (Berkeley: University of California Press, 1993), 137.

276 Trauschweizer, 502; Kaplan and Kellner, 103.

277 Binder, 330.

${ }^{278}$ Kaplan and Kellner, 117; Binder, 331. 
American relationships with Belgium, the Netherlands, Germany, and Italy. De Gaulle’s professional respect for Lemnitzer resulted in him personally presenting Lemnitzer with the highest French military award the Grand Cross of the Legion of Honor at the departure of Supreme Headquarters Allied Powers Europe headquarters’ ceremony. ${ }^{279}$ In the process of relocating Supreme Headquarters Allied Powers Europe headquarters the alliance relationship between the remaining member states strengthened because of the required coordination, teamwork, and resource pooling necessary to reach Lemnitzer's desired end state. ${ }^{280}$ Relocating Supreme Headquarters Allied Powers Europe headquarters from France created economic opportunities in Western Europe, particularly for NATO countries gaining income associated with the American dollar from basing locations. Lemnitzer's diplomatic actions as the commander in chief of the US European Command and Supreme Allied Commander Europe strengthened the alliances between North Atlantic Treaty Organization member states with the adoption of the 7.62 millimeters cartridge for standardization and the relocation of Supreme Headquarters Allied Powers Europe headquarters from France.

General Bonesteel wrote a chapter of the book Issues of National Security in the 1970s titled “The Meaning of National Military Power Today and Tomorrow” and dedicated it to Colonel George A. Lincoln. ${ }^{281}$ In this chapter, Bonesteel describes his views about the war against communism as a global conflict of ideological spectrums. ${ }^{282}$ He viewed the potential conflict as one with open society and democracy at one end and a closed society with communism at the other. ${ }^{283}$ Bonesteel believed the role of national militaries in the future is to provide security and defense for their nations' to ensure survival while relying on the United

\footnotetext{
${ }^{279}$ Kaplan and Kellner, 105; Binder, 331.

${ }^{280}$ Kaplan and Kellner, 110; Binder, 333.

${ }^{281}$ Bonesteel, “The Meaning of National Military Power Today and Tomorrow,” 60-74.

282 Ibid., 63.

283 Ibid.
} 
Nations or other alliances for protection and freedom of choice in their governance style. ${ }^{284} \mathrm{He}$ also believed that the concept of nuclear disarmament agreements without enforcement mechanisms would not be successful, as post-World War I disarmament agreements between nations failed dismally to be effective. ${ }^{285}$ Bonesteel's underlying theme emphasized the importance of the United States and the United Nations to deter the spread of communism by protecting nations without the military capability and power to do so themselves.

${ }^{284}$ Bonesteel, “The Meaning of National Military Power Today and Tomorrow,” 64-67. ${ }^{285}$ Ibid., 68. 


\section{Conclusion}

General Lyman L. Lemnitzer and General Charles H. Bonesteel III demonstrate the need for the Army to understand and value manager leadership at the same level of heroism on the battlefield. Their leadership style illustrated the manager emphasis on war as an organizational problem that is won or lost by efficiently focusing the coordination of personnel and resources

effectively at the battlefield's decisive points. ${ }^{286}$ Lemnitzer and Bonesteel's eighty-seven years of total service in the US Army improved the incorporation of ways and means that contributed to the US Army's understanding of operational art from their actions with regards to planning operations, institutional coordination, and driving research and development to facilitate the incorporation of the ways and means available to effectively achieve strategic end states for America.

Generals Lemnitzer and Bonesteel’s careers shared many similarities, while having their distinctive differences. Both generals incorporated ways and means at the tactical and operational levels to accomplish strategic objectives. Both served on many operational and strategic level staffs and commanded troops up to the Army level. Their participation in Project Solarium in 1953 gave both men a greater understanding and appreciation than their peers on the background of the national policy for countering the Soviet Union. The actions of each general while they commanded USFK at different times helped empower the ROK military capabilities while reducing the US military requirements in Korea.

Lemnitzer’s career distinctions from Bonesteel include: he planned Allied invasion of North Africa campaign during World War II, orchestrated the surrender of German troops in Italy, facilitated the alliance concept of military assistance and shaped NATO in the late 1940s,

${ }^{286}$ Linn, 8-9. 
advanced Army space exploration in 1958, and undertook international relations as a soldierdiplomat. $^{287}$

Bonesteel's career distinctions include: procurement of the DUKW and Bailey Bridge to enhance Allied mobility during World War II, participated in staff plans for the campaigns of Sicily, Normandy, and Operation Lucky Strike I and II, planned the conditional surrender of Japan, and drafted the Marshall Plan. Bonesteel's involvement in enhancement, coordination, and expansion of planning and command capabilities ensured greater synchronization and harmonization of operational ways and means toward achieving the strategic end states. Lemnitzer and Bonesteel's direct leadership and involvement at various levels in planning and command enabled them to incorporate numerous ways and means to achieve the desired end states and they both contributed to the US Army's understanding of operational art.

The generals planned numerous World War II operations and shaped Cold War containment doctrine. Generals Lemnitzer and Bonesteel’s incessant drive set necessary conditions to achieve strategic desired end states against the Axis, the Soviets, and communist enemy threats. Lemnitzer and Bonesteel's coordination between domestic agencies, US military services, the Allied nations and their militaries, the North Atlantic Treaty Organization states, and their diplomatic partners were critical to linking ways and means to achieve the desired end states. Their energy in directing research and development resulted in technological advancements which efficiently multiplied US military combat power and capabilities in the air, sea, land, and space realms. The generals' actions critically influenced the Army understanding of operational art to link the ways and means available to achieve the desired end states. Lemnitzer

${ }^{287}$ Binder, 148. A possible future research project was uncovered during this research. Lemnitzer's plane flights in August of 1945 from Europe to America for leave made for an interesting note in his diary: "Transferred to another plane filled with nurses and WACs [Women's Army Corps] all in various degrees of pregnancy. Long flight toward Stephensville, Newfoundland.” A future research project for someone other than this author and outside the scope of this monograph topic could chart the number of pregnancies that occurred before and during deployments to determine how pregnancy patterns during times of war have changed throughout American history. 
and Bonesteel's manager leadership philosophy during times of war and peace were critical to keeping the American Army as the most effective fighting force in each war she entered. 


\section{Bibliography}

Adams, Benson D. Ballistic Missile Defense. New York: American Elsevier, 1971.

Ambrose Stephen E. Eisenhower: Soldier and President: The Renowned One-Volume Life. New York: Simon \& Schuster Paperbacks, 1990.

Army Doctrine Reference Publication (ADRP) 1-02. Terms and Military Symbols. Washington, DC: Headquarters Department of the Army, September 2013.

Army Doctrine Publication (ADP) 3-0. Unified Land Operations. Washington, DC: Headquarters Department of the Army, October 2011.

Army Doctrine Reference Publication (ADRP) 5-0. The Operations Process. Washington, DC: Headquarters Department of the Army, May 2012.

Army Doctrine Reference Publication (ADRP) 6-0. Mission Command. Washington, DC: Headquarters Department of the Army, May 2012.

Army Information Digest. "Annual Meeting of the Association of the US Army: Toward a Modern Army.” Army Information Digest 15 (November 1960): 25.

Army-Navy-Air Force Journal. “Army 'Best Fitted' of All Services for Certain Space Missions, CoS Lemnitzer Says.” Army-Navy-Air Force Journal 97, no. 25 (February 1960): 5 and 23.

Axelrod, Alan. Risk: Adversaries and Allies: Mastering Strategic Relationships. New York: Sterling, 2009. Accessed on March 16, 2015, https://books.google.com.

Barnes, John W. Engineer Memoirs: MG John W. Barnes, USA, Retired. Manuscript from taperecorded interview by Barry W. Fowle at the home of Major General John W. (Jack) Barnes, USA, Retired, at his home in Issaquah, Washington, on 5 April 1995. Washington, DC: Office of History, US Army Corps of Engineers, 1995.

Beck, Alfred M. Technical Services, the Corps of Engineers, the War against Germany. Fort Leavenworth, KS: US Army Center of Military History, 1985.

Beisner, Robert L. and Kurt W. Hanson, eds. American Foreign Relations since 1600: A Guide to the Literature, $2^{\text {nd }}$ ed, v. 2. Santa Barbara, CA: ABC-CLIO, 2003.

Behrman, Greg M. The Most Noble Adventure: The Marshall Plan and the Time When America Helped Save Europe. New York: Free Press, 2007.

Bell, William Gardner. Commanding Generals and Chiefs of Staff, 1775-2005: Portraits \& Biographical Sketches. Washington, DC: Government Printing Office, 2010.

Berryman, Craig. “The Search for a Cold War Grand Strategy: NSC 68 \& 162.” Master's thesis, School of Advanced Military Studies, United States Army Command and General Staff College, Fort Leavenworth, Kansas, May 22, 2014. Accessed February 11, 2015, http://cgsc.contentdm.oclc.org/utils/getdownloaditem/collection/p4013coll3/id/3192/filen ame/3193.pdf/mapsto/pdf/type/singleitem.

Binder, L. James. Lemnitzer: A Soldier for His Time. Washington, DC: Brassey’s Books, 1997. 
Bischof, Gunter, Stefan Karner, and Barbara Stelzl-Marx, eds. The Vienna Summit and its Importance in International History. Lanham, MD: Lexington Books, 2014. Accessed March 16, 2015, https://books.google.com.

Bissell, Richard M., Jr. “Oral History Interview with Richard M. Bissell, Jr.” Interviewed by Theodore A. Wilson and Richard D. McKinzie at East Hartford, CT on July 9, 1971. Harry S. Truman Library and Museum website. Accessed March 24, 2015, http://www.trumanlibrary.org/oralhist/bissellr.htm\#28.

Blight, James G. and Janet M. Lang. The Fog of War: Lessons from the Life of Robert S. McNamara. Lanham, MD: Rowman and Littlefield, 2005.

Blumenson, Martin. Mark Clark: The Last of the Great World War II Commanders. New York: Congdon and Weed, 1984.

- United States Army in World War II, Mediterranean Theater of Operations: Salerno to Cassino. Washington, DC: Office of the Chief of Military History, 1969.

Bogle, Lori Lyn, ed. The Cold War: National Security Policy Planning from Truman to Reagan and from Stalin to Gorbachev. New York: Routledge, 2001. Accessed March 16, 2015, https://books.google.com.

Bolger, Daniel P. Scenes from an Unfinished War: Low Intensity Conflict in Korea, 1966-1969, Leavenworth Papers no 19. Fort Leavenworth: Combat Studies Institute, 1991.

Bonesteel, Charles H., III. “General Charles H. Bonesteel III, US Army Retired,” Interviewed by Lieutenant Colonel Robert St. Louis, US Army, in Arlington, VA, on November 9, 1972, interview Tape B-33 through Tape B-38, transcripts, Volume I; US Army Military History Institute (MHI); 221.01 Permanent Vol. I; HRC 314.82 Bonesteel, Gen. Charles H., III; Senior Officers Oral History Program by the US Army War College - MHI; Project 73-2; Carlisle Barracks, PA; 17013-5008, 1973.

Bowie, Robert R. and Richard H. Immerman. Waging Peace: How Eisenhower Shaped an Enduring Cold War Strategy. New York: Oxford University Press, 1998.

Bozo, Frederic. Two Strategies for Europe: De Gaulle, the United States, and the Atlantic Alliance: Two Strategies for Europe. Translated by Susan Emanuel. Lanham, MD: Rowman and Littlefield, 2001. Accessed March 16, 2015, https://books.google.com.

Bradley, Omar. A Soldier’s Story. New York: Henry Holt, 1951.

Burns, Richard Dean and Joseph M. Siracusa. A Global History of the Nuclear Arms Race: Weapons, Strategy, and Politics, v. 1. Santa Barbara, CA: ABC-CLIO, 2013. Accessed March 16, 2015, https://books.google.com.

Cantwell, Gerald T. Citizen Airmen: A History of the Air Force Reserve, 1946-1994. Washington, DC: Government Printing Office, 1997.

Carpenter, Ted Galen, ed. NATO at 40: Confronting a Changing World. Lexington, VA: Cato Institute, 1990.

Clarke, Rupert. With Alex at War: From the Irrawaddy to the Po, 1941-1945. South Yorks, Great Britain: Leo Cooper, 2000. 
Cline, Ray S. United States Army in World War II: The War Department: Washington Command Post: The Operations Division. Washington, DC: Office of the Chief of Military History, Department of the Army, 1951. Accessed March 16, 2015, http://www.history.army.mil/ books/wwii/WCP/Chapter XVI.htm\#p327.

Collins, J. Lawton. Lightning Joe: An Autobiography. Baton Rouge: Louisiana State University Press, 1979.

Converse, Elliott V., III. Rearming for the Cold War, 1945-1960: History of Acquisition in the Department of Defense. v. 1. Washington, DC: Historical Office of the Secretary of Defense, 2012. Accessed February 11, 2015, http://www.dtic.mil/dtic/tr/fulltext/ u2/a560470.pdf.

Cosgrove, Michael H. The Cost of Winning: Global Development Policies and Broken Social Contracts. New Brunswick, NJ: Transaction Publishers, 1996. Accessed March 16, 2015, https://books.google.com.

Crosswell, D.K.R. Beetle: The Life of General Walter Bedell Smith. Lexington: University Press of Kentucky, 2010.

Davis, Robert T., II. The Challenge of Adaptation: The US Army in the Aftermath of Conflict, 1953-2000. The Long War Series Occasional Paper 27. Fort Leavenworth, KS: Combat Studies Institute Press, 2008.

Dimitrakis, Panagiotis. Military Intelligence in Cyprus: From the Great War to Middle Ease Crises. New York: Palgrave Macmillan, 2010.

Donovan, Robert J. Conflict and Crisis: The Presidency of Harry S. Truman, 1945-1948. Columbia: University of Missouri Press, 1996.

Dupuy, R. Ernest and Trevor N. Dupuy. The Encyclopedia of Military History: From 3500 B.C. to the Present. New York: Harper and Row, 1970.

Eisenhower, Dwight D. "Letter to Brigadier General Bonesteel” letter. The President of the United States (February 6, 1956), Document 29171. White House Office, National Security Council Staff: Papers, 1948-61, Disaster File, Box No. 2, Dwight D. Eisenhower Library.

Enthoven, Alain C., and K. Wayne Smith. How Much is Enough?: Shaping the Defense Program, 1961-1969. New York: Harper and Row, 1971.

Fairchild, Byron R., and Walter S. Poole. The Joint Chiefs of Staff and National Policy, 19571960, v. 8. Washington, DC: Office of Joint History, 2000.

Fivecoat, David G. “American Landpower and Modern US Generalship.” Review of Tom Rick’s The Generals: American Military Command from World War II to Today. Parameters 42/43 (Winter-Spring 2013): 69-78.

Freedman, Lawrence. Kennedy’s Wars: Berlin, Cuba, Laos, and Vietnam. New York: Oxford University Press, 2000.

Gaddis, John Lewis. Strategies of Containment: A Critical Appraisal of Postwar American National Security Policy. Oxford: Oxford University Press, 1982. Accessed April 16, 2015, https://books.google.com. 
Gebhardt, James F. Eyes Behind the Lines: US Army Long Range Reconnaissance and Surveillance Units. Global War on Terrorism Occasional Paper 10 revised edition. Fort Leavenworth, KS: Combat Studies Institute Press, 2005.

Gordon, Lincoln. “Oral History Interview with Lincoln Gordon.” Interviewed by Richard D. McKinzie in Washington, DC on July 17, 1975. Harry S. Truman Library and Museum website. Accessed March 24, 2015, http://www.trumanlibrary.org/oralhist/gordonl.htm.

Great Britain Admiralty. His Majesty's Submarines, th $^{\text {th }}$ ed. Bennington, VT: Merriam Press, 2007. Accessed March 16, 2015, https://books.google.com.

Haynes, Richard F. The Awesome Power: Harry S. Truman as Commander in Chief. Baton Rouge: Louisiana State University Press, 1973.

Harriman, W. Averell. “Oral History Interview with W. Averell Harriman.” Interviewed by Richard D. McKinzie and Theodore A. Wilson in Washington, DC during 1971. Harry S. Truman Library and Museum. Accessed March 24, 2015, http://www.trumanlibrary.org/ oralhist/harriman.htm\#16.

Harpur, Brian. A Bridge to Victory: The Untold Story of the Bailey Bridge. London: H.M. Stationery Office, 1991.

Heiskell, Andrew. “General Gavin Tells What U.S. Needs to Meet Crisis of Limited War.” Life 45, no. 4 (July 28, 1958): 89. Accessed March 16, 2015, https://books. google.com.

Hendrickson, Ryan C. Diplomacy and War at NATO: The Secretary General and Military Action after the Cold War. Columbia: University of Missouri Press, 2006.

Hellegers, Dale M. We the Japanese People: World War II and the Origins of the Japanese Constitution. Redwood City, CA: Stanford University Press, 2001.

Higham, Robin and Mark Parillo, eds. The Influence of Airpower upon History: Statesmanship, Diplomacy, and Foreign Policy since 1903. Lexington: University Press of Kentucky, 2013.

Historical Office, Office of the Secretary of Defense. Department of Defense Key Officials, 19472004. Washington, DC: Office of the Secretary of Defense, Historical Office, 2004.

Holland, Lauren. Weapons Under Fire. New York: Routledge, 1997. Accessed March 16, 2015, https://books.google.com.

Howze, Hamilton H. A Cavalryman's Story: Memoirs of a Twentieth-Century Army General. Washington, DC: Smithsonian Institution Press, 1996.

Isaacson, Walter, and Evan Thomas. The Wise Men: Six Friends and the World They Made: Acheson, Bohlen, Harriman, Kennan, Lovett, McCloy. New York: Simon and Schuster, 1986.

Joint Publication (JP) 1-02. Department of Defense Dictionary of Military and Associated Terms. Washington, DC: Joint Staff Pentagon, October 2013.

Jordan, Amos A., Jr., ed. Issues of National Security in the 1970s. New York: Frederick A. Praeger, 1967.

Jordan, Robert S., ed. Generals in International Politics. Lexington: University Press of Kentucky, 1987. 
Kaplan, Lawrence S. NATO and the United States: The Enduring Alliance. Lyman L. Lemnitzer Center for NATO Studies, Kent State University. Boston: Twayne, 1988.

Kaplan, Lawrence S., Ronald Dean Landa, and Edward J. Drea. History of the Office of the Secretary of Defense, v. 5: The McNamara Ascendancy, 1961-1965. Washington, DC: Office of the Secretary, Historical Office, 2006.

Kellner, Kathleen Frances Anne. Broker of Power: General Lyman L. Lemnitzer. PhD diss., Kent State University, 1987. Accessed March 16, 2015, https://books.google.com.

Khong, Yuen Foong. Analogies at War: Korea, Munich, Dien Bien Phu, and the Vietnam Decisions of 1965. Princeton, NJ: Princeton University Press, 1992. Accessed March 16, 2015, https://books.google.com.

Kissinger, Henry. Nuclear Weapons and Foreign Policy. New York: Harper \& Brothers, 1957.

Krebs, Ronald R. Dueling Visions: U.S. Strategy toward Eastern Europe under Eisenhower. College Station, TX: Texas A \& M University Press, 2001.

Kuisel, Richard F. Seducing the French: the Dilemma of Americanization. Berkeley: University of California Press, 1993. Accessed March 16, 2015, https://books.google.com.

Lemnitzer, Lyman L. “Why We Need a Modern Army,” Army 10, no. 2 (September 1959): 1622.

Lingen, Kerstin von. Allen Dulles, the OSS, and Nazi War Criminals: The Dynamics of Selective Prosecution, New York: Cambridge University Press, 2013. Accessed March 16, 2015, https://books. google.com.

Linn, Brian McAllister. The Echo of Battle: The Army's Way of War. Cambridge: Harvard University Press, 2007.

Martin, Harold H. 'Starlifter: The C-141, Lockheed's High Speed Flying Truck.' Accessed March 20, 2015, http://c141heaven.info/dotcom/truck/starlifter018.php.

Mastny, Vojtech, Sven G. Holtsmark, and Andreas Wenger, eds. War Plans and Alliances in the Cold War: Threat Perceptions in the East and West. New York: Routledge, 2006. Accessed March 16, 2015, https://books.google.com.

Matlock, Clifford C. "Second Oral History Interview with Clifford C. Matlock.” Interviewed by Richard D. McKinzie in Waynesville, NC on June 6, 1974. Harry S. Truman Library and Museum. Accessed March 24, 2015, http://www.trumanlibrary.org/oralhist/matlock.htm.

McGovern, Terrance C. and Mark A. Berhow. American Defenses of Corregidor and Manila Bay, 1898-1945. Osceola, WI: Osprey, 2003.

McMaster, H.R. Dereliction of Duty: Lyndon Johnson, Robert McNamara, the Joint Chiefs of Staff, and the Lies that Led to Vietnam. New York: Harper Collins Publishers, 1997.

Mieczkowski, Yanek. Eisenhower's Sputnik Moment: The Race for Space and World Prestige. Ithaca, NY: Cornell University Press, 2013.

Millett, Allan R., Peter Maslowski, and William B. Feis. For the Common Defense: A Military History of the United States from 1607-2012, $3^{\text {rd }}$ ed. New York: Free Press, 2012.

Morris-Suzuki, Tessa. Exodus to North Korea: Shadows from Japan's Cold War. Lanham, MD: Rowman and Littlefield, 2007. Accessed March 16, 2015, https://books.google.com. 
Murray, Williamson, ed. Army Transformation: A View from the U.S. Army War College. Carlisle, PA: U.S. Army War College Strategic Studies Institute, 2001.

Nash, Frank C. "Memorandum for the Executive Secretary to National Security Council, Designation of Board Assistants.” The Assistant Secretary of Defense (September 22, 1953). White House Office, National Security Council Staff: Papers, 1948-61, Disaster File, Box No. 2, Dwight D. Eisenhower Library.

Neufeld, Michael J. Von Braun: Dreamer of Space, Engineer of War. New York: Vintage Books, 2008. Accessed March 15, 2015, https://books.google.com.

Nixon, Richard M. Public Papers of the Presidents of the United States: Richard M. Nixon, 1969. Washington, DC: Government Printing Office, 1971. Accessed March 15, 2015, http://quod.lib.umich.edu/p/ppotpus/4731731.1969.001/566?rgn=full+text; view=image; q1=lemnitzer.

Oberdorfer, Don. The Two Koreas: A Contemporary History. New York: Basic Books, 1997.

Ohly, John H. “Oral History Interview with John H. Ohly.” Interviewed by Richard D. McKenzie and Theodore A. Wilson in McLean, VA on November 30, 1971. Harry S. Truman Library and Museum website. Accessed March 24, 2015, http://www.trumanlibrary.org/ oralhist/ohly.htm\#27.

Osgood, Kenneth Alan. Total Cold War: Eisenhower's Secret Propaganda Battle at Home and Abroad. Lawrence: University Press of Kansas, 2006. Accessed March 16, 2015, https://books.google.com.

Patterson, David S., Paul Claussen, Evan M. Duncan, and Jeffrey A. Soukup, eds. Foreign Relations of the United States, 1961-1963, v. 25: Organization of Foreign Policy; Information Policy; United Nations; Scientific Matters. Washington, DC: Government Printing Office, 2001. Accessed March 16, 2015, https://books.google.com.

Patton, George Smith, Jr., and Paul D. Harkins. War as I Knew It. Boston: Houghton Mifflin, 1947.

Perkins, Ken. Weapons and Warfare: Conventional Weapons and their Roles in Battle. London: Brassey’s Defence Publishers, 1987.

Perret, Geoffrey. There's a War to be Won: The United States Army in World War II. New York: Random House, 1991.

Poole, Walter S. The Joint Chiefs of Staff and National Policy, 1961-64, v. 8. Washington, DC: Office of Joint History, 2011.

Porter, Paul R. “Oral History Interview with Paul R. Porter.” Interviewed by Richard D. McKinzie and Theodore A. Wilson in Reston, VA on November 30, 1971. Harry S. Truman Library and Museum website. Accessed March 24, 2015, http://www.trumanlibrary.org/oralhist/ porterpr.htm.

Prados, John. Safe for Democracy: The Secret Wars of the CIA. Chicago: Ivan R. Dee, 2006.

Rimanelli, Marco. The A to Z of NATO and Other International Security Organizations. Lanham, MD: Scarecrow Press, 2009. 
Rose, Patrick. "Allies at War: British and US Army Command Culture in the Italian Campaign, 1943-1944,” Journal of Strategic Studies 36, no. 1 (February 12, 2013): 42-75. Accessed February 11, 2015, http://dx.doi.org/10.1080/01402390.2012.745398.

Ross, Steven T., ed. U.S. War Plans, 1938-1945. Boulder, CO: Lynne Rienner, 2002.

Rozett, Robert, and Shmuel Spector, eds. Encyclopedia of the Holocaust. Jerusalem, Israel: Jerusalem Publishing House, 2000. Accessed March 16, 2015, https://books.google.com.

Rusk, Dean. Written quote. Harry S. Truman Library and Museum website. Accessed March 24, 2015, http://www.trumanlibrary.org/whistlestop/study_collections/korea/large/ world.htm.bak.

—. As told to Richard Rusk. As I Saw It. Edited by Daniel S. Papp. New York: W.W. Norton, 1990.

Salter, Michael. Nazi War Crimes, US Intelligence and Selective Prosecution at Nuremberg: Controversies Regarding the Role of the Office of Strategic Services. New York: Routledge-Cavendish, 2007. Accessed March 16, 2015, https://books.google.com.

Sandler, Stanley, ed. The Korean War: An Encyclopedia. New York: Garland, 1995.

Schaller, Michael, and George Rising. The Republican Ascendancy: American Politics, 19682001. Wheeling, IL: Harlan Davidson, 2002.

Schifferle, Peter J. America's School for War: Fort Leavenworth, Officer Education, and Victory in World War II. Lawrence: University Press of Kansas, 2010.

Schnabel, James F. Policy and Direction the First Year. Washington, DC: Center of Military History, 1992.

Schulimson, Jack. The Joint Chiefs of Staff and the War in Vietnam, 1960-68, Part 1. Washington, DC: Office of Joint History, 2011. Accessed on March 20, 2015, http://www.dtic.mil/doctrine/doctrine/ history/jcsvietnam_pt1.pdf.

Schrader, Charles R. History of Operations Research in the United States Army, 3, 1973-1995. Washington, DC: Center of Military History, 2009.

Sebree, Edmund B. Leadership at Higher Levels of Command as Viewed by Senior and Experienced Combat Commanders. Presidio of Monterey, CA: U.S. Army Leadership Human Research Unit, 1961. Accessed March 22, 2015, https://www.dtic.mil/dtic/ tr/fulltext/u2/478740.pdf.

Siracusa, Joseph M. Encyclopedia of the Kennedys: The People and Events that Shaped America. Santa Barbara, CA: ABC-CLIO, 2012. Accessed March 16, 2015, https://books. google.com.

Soffer, Jonathan M. General Matthew B. Ridgway: From Progressivism to Reaganism, 18951993. Westport, CT: Praeger Publishers, 1998.

Sorley, Lewis. Honorable Warrior: General Harold K. Johnson and the Ethics of Command. Lawrence: University Press of Kansas, 1998.

Spector, Ronald H. In the Ruins of Empire: The Japanese Surrender and the Battle for Post War Asia. New York: Random House, 2007. 
Swenson-Wright, John. Unequal Allies?: United States Security and Alliance Policy Towards Japan, 1945-1960. Stanford, CA: Stanford University Press, 2005.

Talbot, David. Brothers: The Hidden History of the Kennedy Years. New York: Free Press, 2007.

Taylor, Maxwell D. Swords and Plowshares. New York: W.W. Norton, 1972.

Technical Manual (TM) 5-277, Panel Bridge, Bailey Type, M2, Department of the Army Technical Manual. Washington, DC: Headquarters Department of the Army, 1986.

Temple, L. Parker, III. Shades of Gray: National Security and the Evolution of Space Reconnaissance. Reston, VA: American Institute of Aeronautics and Astronautics, Inc., 2005.

Thompson, Leroy. The M1 Garand. Westminster, MD: Osprey, 2012.

Thurmond, James Strom. Tribute Speech, “Tribute to the Late General Frank S. Besson, Jr.,” Senate Floor Session 105-1, 143 Congressional Record Section 7947, Vol. 143 No. 105 Pg. S7947, July 23, 1997. Accessed February 11, 2015, http://congressional.proquest. com/congressional/docview/t17.d18.c4b5e48811002966?accountid=28992.

Trauschweizer, Ingo. The Cold War U.S. Army: Building Deterrence for Limited War. Lawrence: University Press of Kansas, 2008.

Tucker, Spencer C. Who’s Who in Twentieth Century Warfare. New York: Routledge, 2001.

, ed. The Encyclopedia of the Vietnam War: A Political, Social, and Military History second edition. Santa Barbara, CA: ABC-CLIO, 1998.

— 16, 2015, https://books.google.com.

Tucker, Todd. Atomic America: How a Deadly Explosion and a Feared Admiral Changed the Course of Nuclear History. New York: Free Press, 2009. Accessed March 16, 2015, https://books.google.com.

United States Congress. Nomination of Gen. Lyman L. Lemnitzer to be Chief of Staff of the Army: Hearing Before the Committee on Armed Services, United States Senate, Eighty-sixth Congress, First Session, on the Nomination of Gen. Lyman L. Lemnitzer, U.S. Army, to be Appointed as Chief of Staff of the Army for 2 Years, Vice Gen. Maxwell D. Taylor. Washington, DC: U.S. Government Printing Office, April 23, 1959. Accessed March 16, 2015, http://congressional. proquest.com/congressional/docview/t05.d06.hrg-1959-sas0018_index?accountid= 28992.

United States Congress. Nominations: General L. L. Lemnitzer, Chairman, JCS, and General G. H. Decker, Army Chief of Staff: Hearings Before the United States Senate Committee on Armed Services, Eighty-Sixth Congress, Second Session. Washington, DC: US Government Printing Office, August 20, 1960. Accessed March 16, 2015, http://congressional.proquest.com/ congressional/docview/t05.d06.hrg-1960-sas-0013_ index?accountid=28992.

Uslu, Nasuh. The Turkish-American Relationship Between 1947 and 2003: The History of a Distinctive Alliance. Hauppauge, NY: Nova Science Publishers, Inc., 2003. Accessed March 16, 2015, https://books.google.com.

Weigley, Russell P. History of the United States Army. New York: Macmillan, 1967. 
Weizsacker, C.F. von. “European Armaments in the 1980s.” Bulletin of the Atomic Scientists 36, no. 10 (December 1980): 8. Accessed March 16, 2015, https://books.google.com.

West Point Association of Graduates, Assembly Magazine 28-29 (1969): 39.

White, Nigel D. The United Nations System: Towards International Justice. Boulder, CO: Lynne Rienner, 2002. Accessed March 16, 2015, https://books.google.com.

Wicker, Tom, Arthur M. Schlesinger, Jr. Dwight D. Eisenhower: The American Presidents Series: the $34^{\text {th }}$ President. New York: Times Books, 2014. Accessed March 16, 2015, https://books.google.com.

Williams, Geoffrey. The Permanent Alliance: The European-American Partnership, 1945-1984. Leyden, Netherlands: A.W. Sijthoff, 1977. Accessed March 16, 2015, https://books.google.com.

Williams, James W. A History of Army Aviation: From its Beginnings to the War on Terror. Bloomington, IN: iUniverse, Inc., 2005.

Wilson, C.E. "Brigadier General Bonesteel Letter of Recommendation to President Eisenhower" letter to President Eisenhower. The Secretary of Defense (February 2, 1956), Document 29169. White House Office, National Security Council Staff: Papers, 1948-61, Disaster File, Box No. 2, Dwight D. Eisenhower Library.

Wilson, Theodore A. The Marshall Plan, 1947-1951. Headline Series, No. 236, June 1977. New York: Foreign Policy Association, 1977.

Worley, D. Robert. Aligning Ends, Ways, and Means: An Examination of the U.S. National Security Strategy. Raleigh, NC: Lulu.com, 2006. Accessed March 16, 2015, https://books.google.com. 